\title{
45. GEOLOGIC HISTORY OF WODEJEBATO GUYOT ${ }^{1}$
}

\author{
Jonathan M. Lincoln, ${ }^{2}$ Paul Enos, ${ }^{3}$ Gilbert F. Camoin, ${ }^{4}$ Jim G. Ogg, ${ }^{5}$ and Douglas D. Bergersen ${ }^{6}$
}

\begin{abstract}
Wodejebato Guyot, in the northern Marshall Islands, underwent two distinct eruptive phases during construction of its volcanic edifice. The first began before or during mid-Cenomanian time and ended at the end of Cenomanian time. This phase of eruption produced thick deposits of volcaniclastic debris at Site $869,83 \mathrm{~km}$ southeast of the guyot, and a vegetated volcanic island that was at least partially submerged before onset of the second eruptive phase. The second phase of volcanic activity was confined to early Campanian time. Once again, a volcanic island rose above sea level. During this emergent period, a tropical weathering profile, up to $24 \mathrm{~m}$ thick, developed on top of the basalts and breccias of the volcanic island. Carbonate sands, which were later stabilized by encrusting organisms such as red algae, were laid down in late Campanian time as subsidence of the underlying edifice carried the summit down to, and eventually below, the sea level. Following the initial transgression of the volcanic island, an algal-coralrudist boundstone reef formed a perimeter ridge at Sites 874 and 877 that resulted in progressively quieter, more restricted depositional environments at Site 873 in the interior of the platform. The carbonate platform may have experienced exposure above sea level in mid-Maastrichtian time. At this time, any sediments at Sites 875 and 876, seaward of the initial perimeter ridge, eroded down to the underlying basalt. The basalt at these seaward sites was soon covered with a ridge, or spit, formed from sands and other debris eroded from the adjacent reef. As the sea level rose again and a new coral-algal-rudist reef reestablished itself on the initial, inner perimeter ridge, sands continued to accumulate into an essentially parallel outer perimeter ridge. Sand shoals also migrated across the lagoonal sediments on the interior of the platform, followed by colonization of these sands by algae and rudist colonies. A second relative sea-level fall in late Maastrichtian time may have eposed the surface of the platform to erosion and meteoric diagenesis. Evidence includes scouring of the terminal carbonate deposits, dissolution in the upper limestone subunits, and isotopic compositions characteristic of diagenesis in meteoric waters. Possible cooling of mid-Maastrichtian oceans and high nutrient levels encountered as the guyot approached the equator may have slowed carbonate production to the point that the platform could not keep up during the subsequent sea-level rise and drowned.
\end{abstract}

\section{INTRODUCTION}

Wodejebato Guyot $\left(12.0^{\circ} \mathrm{N}, 164.9^{\circ} \mathrm{E}\right.$; formerly Sylvania Guyot) is located approximately $74 \mathrm{~km}$ northwest of Pikinni Atoll (formerly Bikini Atoll) in the Ralik Chain of the northern Marshall Islands (Fig. 1). Wodejebato Guyot and Pikinni Atoll share the same volcanic pedestal and are connected by a volcanic ridge at a water depth of approximately $1500 \mathrm{~m}$. The Ralik Chain is the central of three northwest-trending, en echelon chains of seamounts, guyots, and atolls that make up the Marshall Islands. During Ocean Drilling Program (ODP) Leg 143, Site 869 was drilled into the apron southwest of the Wodejebato-Pikinni guyot-atoll pair through nearly $800 \mathrm{~m}$ of a layered succession of sediments that include nearly $600 \mathrm{~m}$ of volcaniclastic debris shed from the nearby atoll-guyot pair (Sager, Winterer, Firth, et al., 1993). Five holes were drilled on Wodejebato Guyot during Leg 144 (Premoli Silva, Haggerty, Rack, et al., 1993): Site 873 is located within the center of the broad guyot, Sites 874 and 877 are located approximately $20 \mathrm{~km}$ north of Site 873 on the inner of two perimeter ridges that bound the northeast side of the guyot, and Sites 875 and 876 are located on an outer perimeter ridge, about $1.5 \mathrm{~km}$ east of Sites 874 and 877 , respectively (Fig. 1). At all five sites drilled on Wodejebato Guyot during Leg 144, limestone typical of a shallow-water carbonate platform was recovered. The results of drilling are herein used to reconstruct the geologic history of Wodejebato Guyot from

\footnotetext{
'Haggerty, J.A., Premoli Silva, L., Rack, F., and McNutt, M.K. (Eds.), 1995, Proc ODP, Sci. Results, 144: College Station, TX (Ocean Drilling Program).

${ }^{2}$ Department of Earth and Environmental Studies, Montclair State University, Upper Montclair, NJ 07043, U.S.A.

${ }^{3}$ Department of Geology, University of Kansas, 120 Lindley Hall, Lawrence, KS 66045, U.S.A.

${ }^{4}$ Centre de Sédimentologie et Paléontologie, U.R.A. 1208 du C.N.R.S., Université de Provence, 3 place Victor Hugo, F-13331 Marseille Cedex 3, France.

${ }^{5}$ Department of Earth and Atmospheric Sciences, Purdue University, West Lafayette, IN 47907, U.S.A.

${ }^{6}$ Department of Geology, University of Sydney, New South Wales 2006, Australia.
}

the eruption of a volcanic pedestal in Cenomanian and in early Campanian times, through its subsidence and accumulation of shallowwater carbonate sediments in late Campanian to Maastrichtian time, to its final drowning in mid to late Maastrichtian time.

\section{PREVIOUS WORK IN THE NORTHERN MARSHALL ISLANDS}

Pikinni and Anewetak Atolls were drilled in 1947 and 1952, respectively, as part of Operation Crossroads (Emery et al., 1954). The deeper of the two holes drilled at Pikinni Atoll penetrated $780 \mathrm{~m}$ of coral-algal, reef-related sediments and reached strata of early Miocene and Oligocene(?) age; volcanic basement was not reached in either hole (Emery et al., 1954; Cole, 1954). A stratigraphic section equivalent to that drilled at Pikinni was penetrated at the top of two holes drilled on Anewetak Atoll, $300 \mathrm{~km}$ west of Pikinni Atoll, in 1952 (Cole, 1957; Schlanger, 1963). Basalt, directly overlain by reef, forereef, and outer-slope sediments of late Eocene age, was reached at depths of 1271 and $1388 \mathrm{~m}$ below Anewetak Atoll. This basalt has recently been dated at $75.9 \pm 0.6 \mathrm{Ma}$ (late Campanian) by ${ }^{40} \mathrm{Ar} /{ }^{39} \mathrm{Ar}$ methods (Lincoln et al., 1993). Seismic-refraction studies at Pikinni Atoll revealed a reflector with high surface relief and a velocity of about $4 \mathrm{~km} / \mathrm{s}$, thought to be the top of the volcanic edifice, at a depth of about $1300 \mathrm{~m}$ (Raitt, 1954). A basement depth of $1500-1600 \mathrm{~m}$ was estimated for Pikinni Atoll from aeromagnetic surveys (Alldredge et al., 1954). Based on similar depths to volcanic basement and similar subsidence histories inferred from biostratigraphic correlation (Cole, 1957), Pikinni Atoll was assumed to be contemporaneous with the edifice beneath Anewetak Atoll.

Dredging on Wodejebato in 1950 recovered basalts and a tuff breccia with cracks filled with phosphatized, planktonic foraminifers of Eocene age (Hamilton and Rex, 1959). Emery et al. (1954) inferred eruption in shallow water from the highly vesicular and scoriaceous nature of the rocks; the high proportion of hyaloclastic material in the dredge hauls indicated submarine eruptions. Similar rocks were re- 

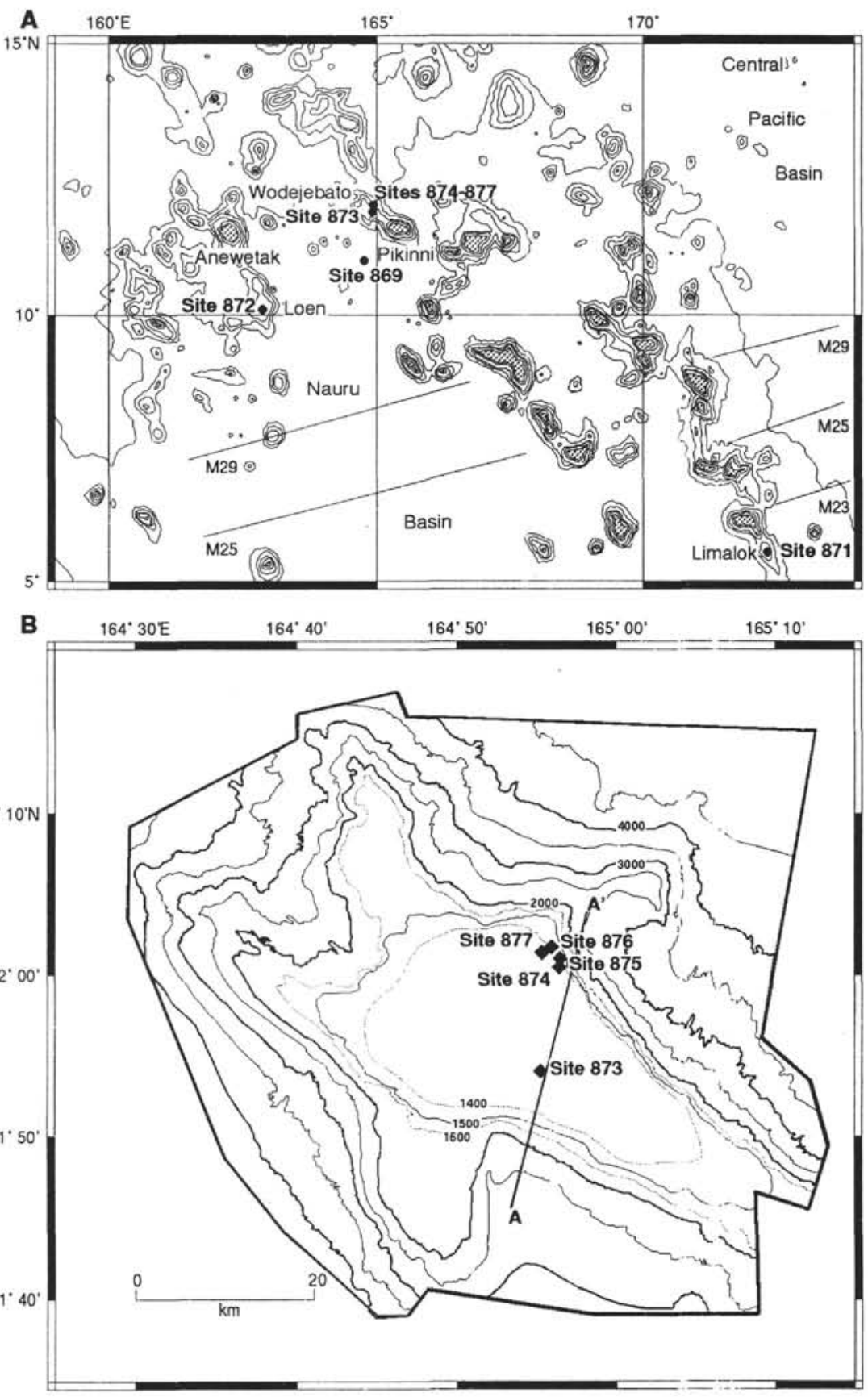

Figure 1. A. Map of the Marshall Islands showing locations discussed in the text. B. Bathymetric map of Wodejebato Guyot compiled from seismic and SeaMARC II surveys (Bergersen, 1993) showing the location of Site 873 in the center of the broad platform relative to Sites $874-877$, drilled on the margin of the guyot. Line $\mathrm{A}-\mathrm{A}^{\prime}$ shows the location of the seismic profile in Figure 2.

covered from the south side of Wodejebato Guyot in 1981 (Petersen et al., 1986). One piece of hyaloclastite contained shallow-water peloids, fragments of a larger benthic foraminifer, calcareous red algae, and bryozoan fragments. Manganese-coated vesicular basalt, hyaloclastite, basalt breccia, and moderately to well-lithified pelagic sediments were recovered from the talus slopes that flank Wodejebato Guyot during a 1988 site survey. Planktonic foraminifers constrain the age of volcanism to be Eocene or older (Lincoln et al., 1993). One sample contains poorly preserved clasts in a matrix with early Tertiary fossils. The clasts contain Late Cretaceous (possibly late Santonian to earliest Campanian) planktonic foraminifers. Rounded basalt pebbles in several conglomerates indicate subaerial or wave erosion of the volcanic edifice. Dredging at the slope break on the south side of Wodejebato Guyot recovered manganese-encrusted, coarse-grained, poorly sorted, shallow-water limestones containing larger benthic foraminifers, calcareous algae, coral fragments, echinoid debris, bry- ozoan fragments, and molluscan debris (Lincoln et al., 1993). The larger foraminifer assemblage in these limestones is similar to a Campanian to Maastrichtian assemblage recovered in turbidites at Deep Sea Drilling Project (DSDP) Site 462 in the Nauru Basin, south of Wodejebato Guyot (Premoli Silva, 1986). Specimens of a primitive orbitoides, possibly $O$. tissoti, were also present in the dredged limestones; the biostratigraphic range of these primitive orbitoids is from early to middle Campanian. Several poorly preserved shell fragments and whole specimens of radiolitid and caprinid rudists were recovered in the same dredge.

Lincoln et al. (1993) provide a summary of the history of volcanism and reef-building in the Marshall Islands based on samples recovered before Legs 143 and 144. Evidence of Cenomanian or older volcanism, uplift, and reef-building is cited for six guyots and seamounts and two DSDP Sites in the Marshall Islands. Evidence for Late Cretaceous volcanism, uplift, and reef-building is cited for 12 
guyots and seamounts and 3 DSDP Sites. In at least four cases, the later stage of volcanism or reef-building is superimposed upon or adjacent to a site of Cenomanian or earlier volcanism. These four cases include the Anewetak Atoll-Lo-en Guyot pair, Ruwituntun Guyot and Look Sea- mount, Lobbadede and Lewa Seamounts, and the Pikinni Atoll-Wodejebato Guyot pair (see Fig. 1 for locations).

\section{GUYOT MORPHOLOGY AND SITE LOCATIONS}

Bergersen (1993; this volume) provide detailed discussions of the major geomorphic features comprising Wodejebato Guyot. Based on integration of seismic surveys, SeaMARC II side-scan sonar images, and dredge results collected during the 1988 site survey and a 1990 survey, Wodejebato Guyot was interpreted to consist of a volcanic edifice with gullied slopes, a reef rim surrounding lagoonal sediments, and a conical cap of pelagic sediments (Bergersen, 1993). The summit of Wodejebato is about $43 \mathrm{~km}$ long and increases in width from less than $12 \mathrm{~km}$ in the southeast to more than $25 \mathrm{~km}$ in the northwest. Four lobes project from the edifice and, along with the ridge connecting Wodejebato with Pikinni Atoll, give the guyot a distinctive "starfish" appearance (Fig. 1B). The first slope break away from the summit of the guyot, inferred to be the rim of the carbonate platform that underlies the cone of pelagic sediments, occurs at a depth of about $1350-1450 \mathrm{~m}$. The flanks of the guyot may be divided into a steep upper slope $\left(20^{\circ}-24^{\circ}\right)$ and a more gently inclined lower slope (about $7^{\circ}$ ); the transition between these two zones is around $2500 \mathrm{~km}$. The cone of pelagic sediments covering Wodejebato guyot reaches a maximum thickness of about $100 \mathrm{~m}$ near the center of the guyot (Fig. 2) and thins toward the outer edge of the summit. Bergersen (1993) identified two seismic facies that onlap a central basement high and interpreted both as lagoonal sediments onlapping a central volcanic peak. Site 873 was drilled into these inferred lagoonal sediments south of the basement high in the interior of the Wodejebato Guyot summit region (Figs. 1 and 2).

Sidescan images and seismic profiles show two perimeter ridges along the lobes formed by the northern and northeastern flank ridges, and along the ridge extending to the southeast toward Pikinni Atoll (Bergersen, 1993; Fig. 3). These ridges are separated by a narrow trough about $50 \mathrm{~m}$ deep. The inner perimeter ridge appears in all seismic profiles crossing the edge of the summit plateau with the exception of the south flank where faulting appears to have removed portions of the original edifice. The outer ridge appears only along the broad lobes formed by the northern and northeastern flank ridges and along the ridge connecting Wodejebato to Pikinni Atoll. The inner perimeter ridge rises above the level of the lagoon sediments. In the region surveyed and drilled during Leg 144, the inner perimeter ridge narrows slightly from $2 \mathrm{~km}$ in the north to $1 \mathrm{~km}$ in the south (Premoli Silva, Haggerty, Rack, et al., 1993; pp. 216-217). In this region, the maximum height of the ridge above the lagoon sediments is about 48 $\mathrm{m}$, and the average height is about $36 \mathrm{~m}$. Lagoonward slopes vary from less than $1^{\circ}$ to $10^{\circ}$, whereas the slopes on the seaward side are up to $15^{\circ}$. Sites 874 and 877 were drilled into the inner ridge along the northeastern perimeter of Wodejebato Guyot. Site 874 is located on the seaward summit of this ridge and Site 877 is located in a slightly more lagoonward position, $0.7 \mathrm{~km}$ northeast of Site 874 (Figs. 1 and 3). Sites 874 and 877 will be discussed together in subsequent sections. Site 875 is located on the outer perimeter ridge of Wodejebato Guyot adjacent to Site 874 and Site 876 is located on the outer perimeter ridge $1.67 \mathrm{~km}$ north of Site 875 (Figs. 1 and 3). Sites 875 and 876 will be discussed together in subsequent sections.

\section{LITHOSTRATIGRAPHY}

Lithostratigraphic summaries for all five sites drilled on Wodejebato Guyot are shown in Figures 4 through 7. A composite stratigraphic summary is shown in Figure 8. Although water depths among the five sites vary by as much as $75 \mathrm{~m}$, much of the variation is caused by the conical pelagic cap that covers Site 873 . No more than a thin veneer of pelagic sediments cover Sites 874-877. All depths plotted on Figure 8 are relative to the seafloor at Site 873 , the shallowest of the sites drilled. Based on this reference point, the top of the carbonate platform at Site 873 in the former lagoon is 13 and $33 \mathrm{~m}$ lower than inner perimeter ridge Sites 874 and 877 , respectively. The top of the platform carbonates at Site 873 is 21 and $11 \mathrm{~m}$ higher than the top of the carbonates at the outer perimeter ridge Sites 875 and 876 , respectively. The base of the carbonate platform (top of the weathered basement surface) is $52.5 \mathrm{~m}$ higher in the lagoon than at inner perimeter ridge Sites 874 and 877 . The base of the carbonate platform (top of the basement weathering surface) is 49.5 and $59 \mathrm{~m}$ higher in the lagoon than at the outer perimeter Sites 875 and 876 , respectively.

\section{Basalts and Volcanic Breccias}

Unit VI at Site 873 (Fig. 4) consists of approximately $28 \mathrm{~m}$ of poorly sorted, olive gray volcanic breccia with angular to subangular clasts (several millimeters to $1.5 \mathrm{~cm}$ in diameter) in a fine-sand to clay-sized matrix that is dusky red in the upper $5 \mathrm{~m}$ and dark gray green in lower portions of the unit (Premoli Silva, Haggerty, Rack, et al., 1993, pp. 159, 184-185). Unit V at Site 873 consists of approximately $29 \mathrm{~m}$ of altered basalt (Fig. 4). Based on mineralogy, most of the basalts are identified as olivine-poor alkalic basalts. One flow unit may consist of hawaiite.

The basalt samples that comprise Unit III at Site 874 (Fig. 5) appear to form a single ankaramite flow. Features such as clinopyroxenes irregularly embayed by altered glass along the edges indicate that the phenocrysts are xenocrysts transported by the host magma (Premoli Silva, Haggerty, Rack, et al., 1993, p. 236). The matrix is an alkali olivine basalt similar to basalt recovered at Site 873 . No volcanic breccia unit was recovered at Site 874 .

At Site 877 the basal Unit IV (Fig. 6) consists of a basaltic breccia that contains clasts of vesicular, plagioclase-clinopyroxene basalt $0.5-2.0 \mathrm{~cm}$ in diameter (Premoli Silva, Haggerty, Rack, et al., 1993, p. 308). The clast outlines are obscured by weathering. The matrix is clay and calcite. Many of the clasts contain irregular vesicles filled with green clay. Calcite occurs in thin subhorizontal veins that replace up to $50 \%$ of the breccia.

Holes $875 \mathrm{C}$ and $876 \mathrm{~A}$ passed directly from limestone into basalt with little or no indication of the weathering profile encountered at other sites on Wodejebato Guyot (Fig. 7). Approximately $85 \mathrm{~cm}$ of alkali olivine basalt, similar to others recovered on Wodejebato Guyot, was recovered from Hole 875C (Premoli Silva, Haggerty, Rack, et al., 1993, p. 278). Secondary pyrite is present along fractures of the basalt and lining some vesicles, suggesting that the reducing conditions prevalent following initial submergence at other sites on Wodejebato Guyot were also present at Site 875 . The uppermost basalts at Site 876 (Unit III) are altered basalt pebbles enclosed by a limestone matrix at the limestone-basalt interface. They may indicate a relatively high-energy depositional environment during submergence that was absent at the inner perimeter ridge and lagoonal sites. Below the limestone-basalt breccia, $14.5 \mathrm{~m}$ of fine-grained alkali basalt and basalt breccias were drilled (Premoli Silva, Haggerty, Rack, et al., 1993, p. 278).

Pringle et al. (this volume) report that the ${ }^{40} \mathrm{Ar} /{ }^{39} \mathrm{Ar}$ ages for lavas from Sites 873-877 on Wodejebato Guyot, as well as ages for basalt dredged from the northeast rift zone of this guyot, range from 85 to $79 \mathrm{Ma}$. Because all of the recovered lavas are reversely magnetized, Pringle et al. (this volume) conclude that these lavas probably erupted during Chron 33R (early Campanian).

\section{Clay Units}

\section{Platform Interior (Site 873)}

Unit IV at Site 873 consists of $19.2 \mathrm{~m}$ of ferruginous clay and claystone first recovered at a depth of 156 meters below seafloor (mbsf) (Fig. 4). The top of Unit IV is recorded in downhole logs, however, at 


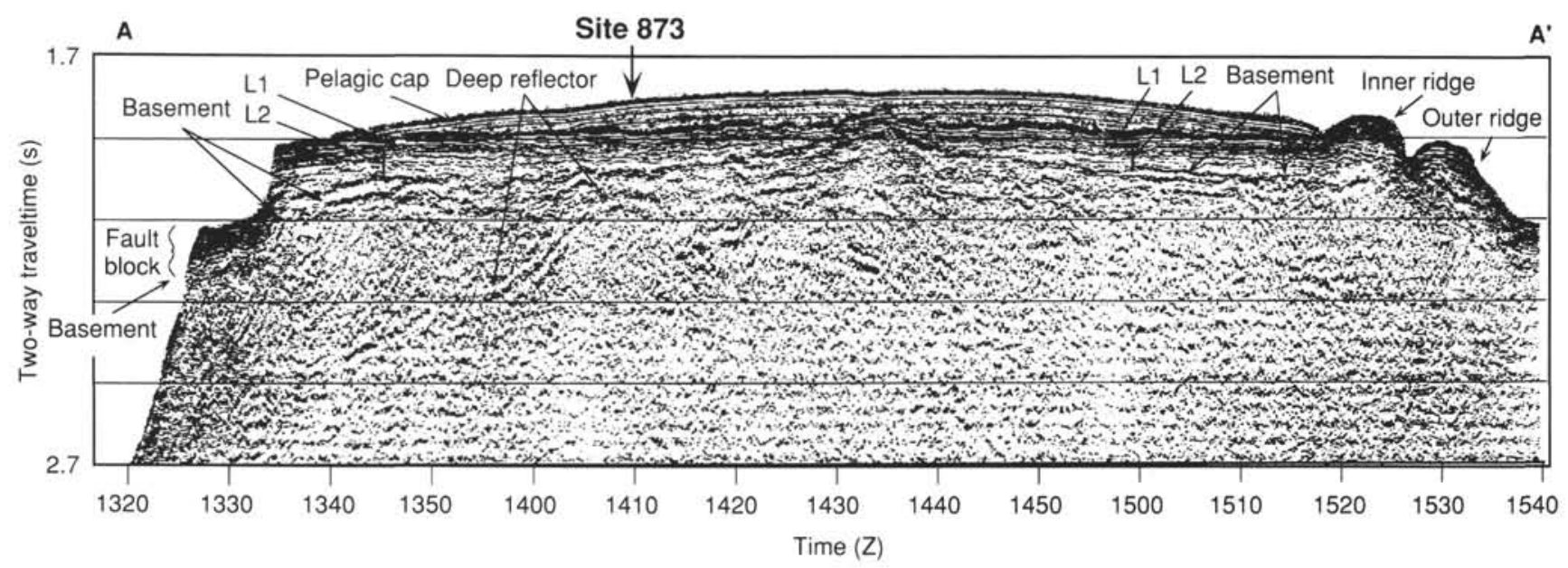

Figure 2. Migrated six-channel seismic profile from which Site 873 (on Wodejebato Guyot) was selected. An arrow marks the location of Site 873 directly above the local high in the deep reflector. The basement reflector (L1) marked on this profile represents the bottom of the carbonate complex. The deep reflector (L2) suggests a change in the character of the basement (from Premoli Silva, Haggerty, Rack, et al., 1993). Location of the profile is shown on Figure 1.
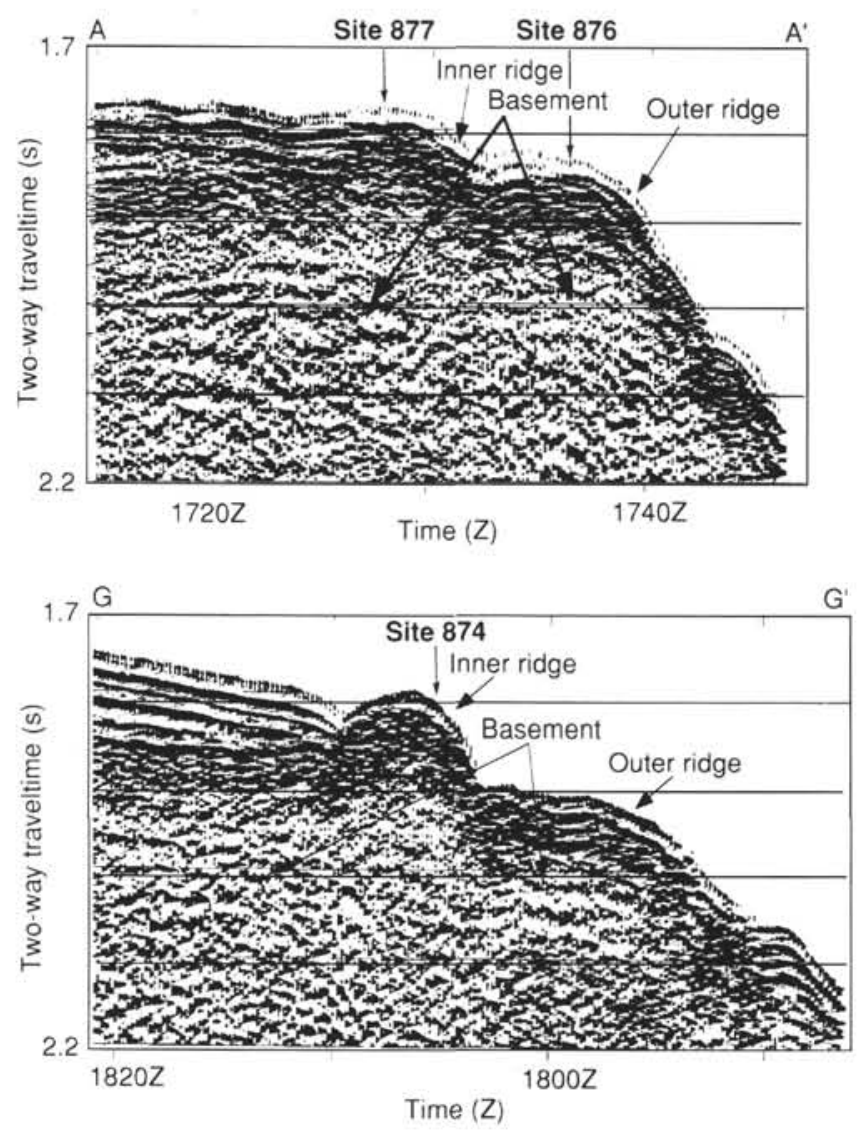

Figure 3. Single-channel seismic profiles across the locations of Sites $874-877$ on Wodejebato Guyot. A packet of strong reflectors overlying a more acoustically massive unit composes the inner ridge. The reflector interpreted as basement is faintly visible on these profiles. a depth of $151.5 \mathrm{mbsf}$ as a sharp increase in thorium and aluminum in the gamma-ray and geochemical logs, a sharp decrease in resistivity, and a sharp increase in borehole diameter (Fig. 4; Premoli Silva, Haggerty, Rack, et al., 1993, p. 159). There is no evidence from core or logs of a gradational contact. The gamma-ray and chemical logs do not show any evidence of a gradual decrease in thorium or aluminum that might be expected if clay was reworked into the overlying limestones. The top of the clay unit is dark red. With increasing depth, the unit becomes olive with dark red to gray mottles. The unit becomes more indurated with depth and textures reminiscent of altered basalt, such as vesicles filled with white zeolites, become apparent.

\section{Inner Perimeter Ridge (Sites 874 and 877)}

The first sedimentary deposits overlying the basalts at Sites 874 and 877 consist of claystone breccia, claystone, organic-rich clay, and argillaceous limestone (Unit III at Sites 874 and 877 on Figs. 5, 6, and 8). Relative to the seafloor at Site 873 , the top of the clays are reached at 203.4 mbsf at Site 874 and at 204 mbsf at Site 877 (see Fig. 8). The tops of the clay units at these two sites are approximately $52 \mathrm{~m}$ lower than the top of the clay unit at Site 873 .

The claystone breccia at the inner perimeter sites consists of dusky red to reddish brown, angular clasts with sizes ranging from $1 \mathrm{~mm}$ up to $4 \mathrm{~cm}$. The overlying claystone is dark brown, gray, and olive green. Pyrite is common in the matrix (up to $4 \%$ ) and forms small aggregates. Subvertical and vertical roots up to $3 \mathrm{~cm}$ long are reported in Premoli Silva, Haggerty, Rack, et al. (1993, p. 295). Textures reminiscent of an igneous breccia are apparent in the lower portions of Unit III at Sites 874 and 877, including clasts of altered basalt, laths of plagioclase, and apparent vesicles filled by zeolites. The contact between the clay and the basalt is gradational and the degree of alteration decreases downward. These clays are thought to be the product of terrestrial weathering of the underlying basalt and basalt breccia (Holmes, this volume). Peat is preserved near the top of the clay unit at Site 877 . The high sulfur content of this peat may be related to bacterial reduction of sulfates provided by marine waters during initial submergence (Buchardt et al., this volume). Gray to black, organic-rich clays at the top of clay units at Sites 874 and 877 contain kerogen-type woody material along with calcareous nannofossils and larger foraminifers (Premoli Silva, Haggerty, Rack, et al., 1993, pp. 234 and 306). Argillaceous limestones at the top of Unit III at Site 877 are intercalated with laminae of black clay and contain thin-shelled mollusc fragments and benthic foraminifers. The preservation of clay and the lack of reworking at the base of the shallow- 
Hole 873A

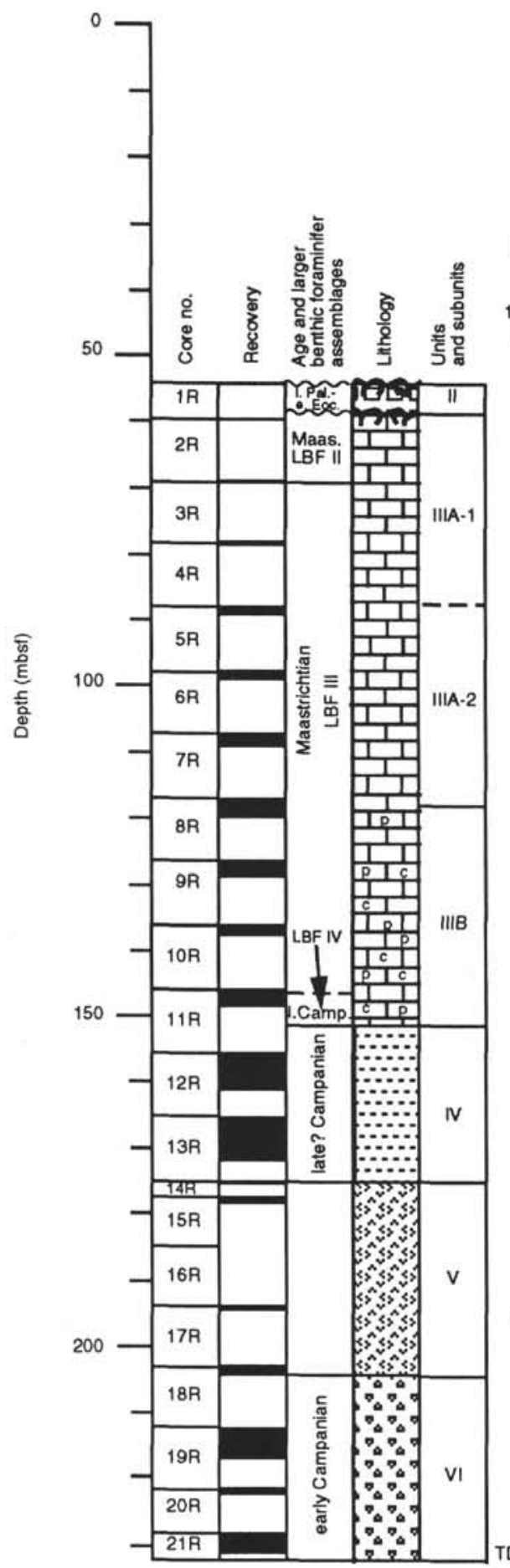

Hole 873B

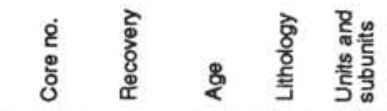

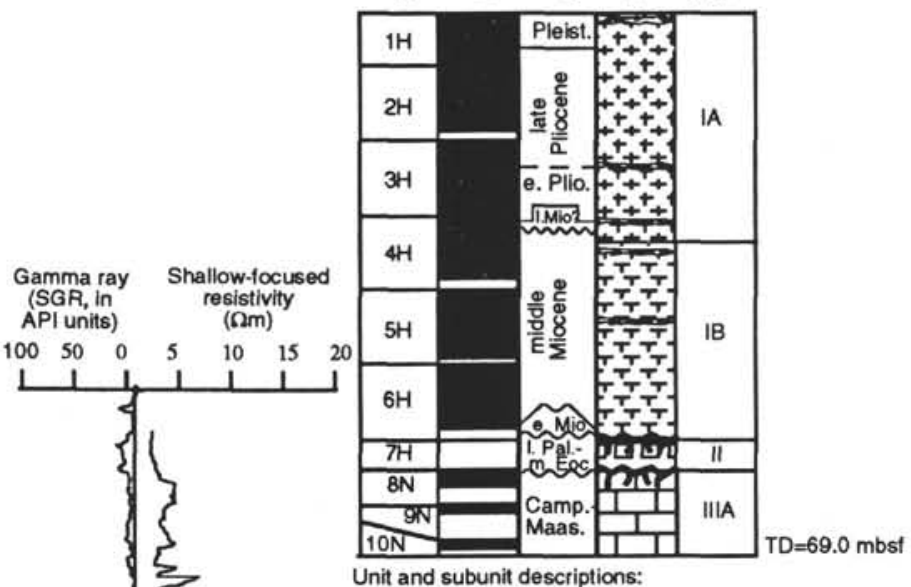

IA: Nannofossil foraminifer ooze

IB: Foraminifer $\infty$ ze

II: Manganese-coated, phosphatic,

limestone conglomerate with

pelagic and neritic components

IIIA: Very pale brown packstone and

grainstone with radiolitid rudists,

miliolid and large benthic foraminifers,

and red (coralline) algae

IIIB: Gray wackestone, packstone, and grainstone with common pyrite

IV: Ferruginous red clay and claystone

V: Altered basalt

VI: Volcanic breccia

Bioturbation

Manganese encrusted

[U] Mixed shallow-water and pelagic conglomerate

Limestone with organic carbon and pyrite

Figure 4. Stratigraphic summary for Site 873 (modified from Lincoln et al., this volume). Larger benthic foraminifer (LBF) assemblages in this figure are defined in the text. 

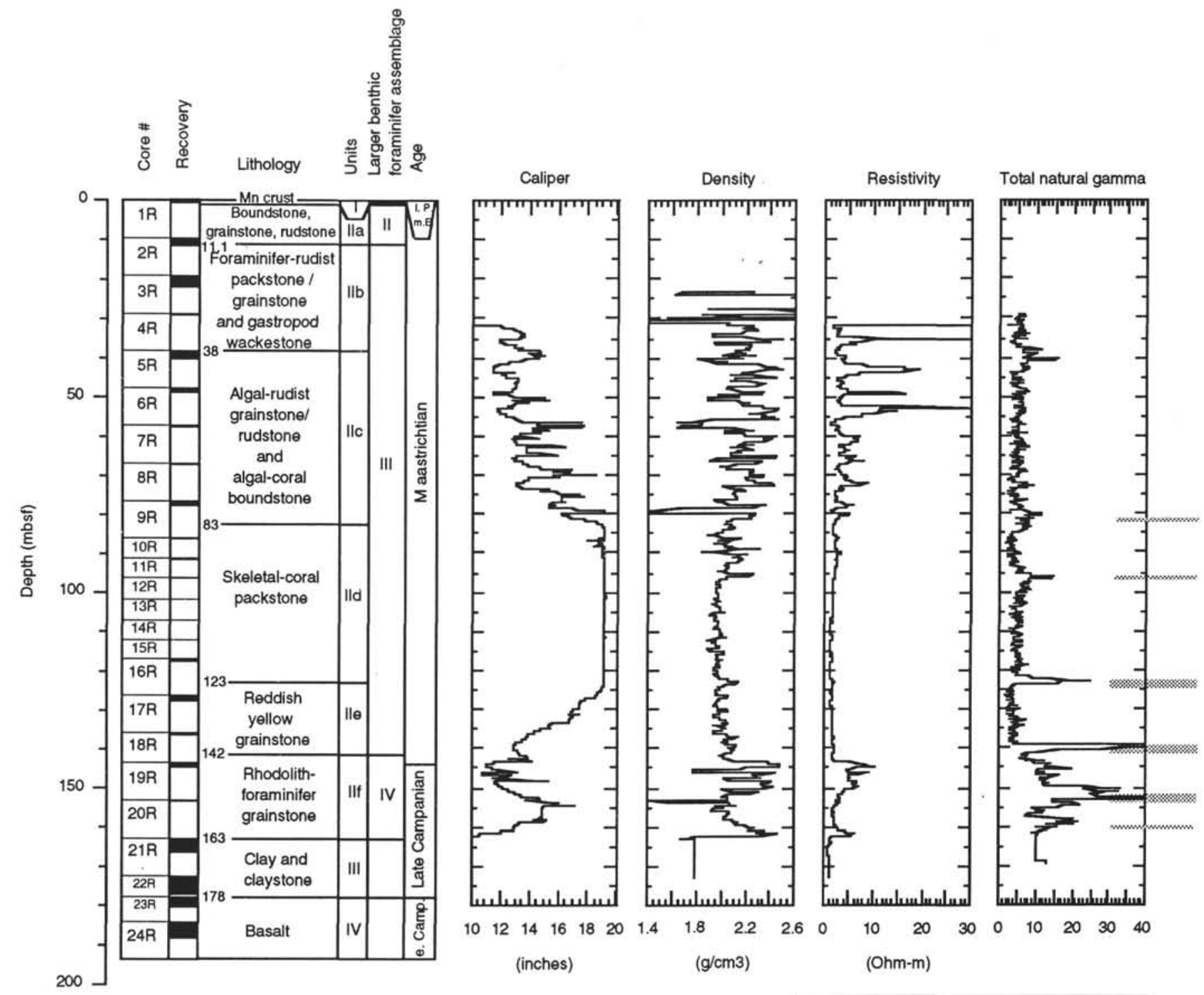

major, minor Gamma peaks

Figure 5. Selected geophysical logs from Site 874 are compared with cored intervals, lithostratigraphy, and biostratigraphic ages. Larger benthic foraminifer (LBF) assemblages are defined in the text. Resistivity is from the medium-penetration phasor-induction (IMPH) tool. Total natural gamma measurements are from the Formation MicroScanner. Caliper (apparent hole diameter) does not record values greater than $48 \mathrm{~cm}$ (from Camoin et al., this volume).

marine deposits suggests either a quiet, shallow-marine environment during initial submergence or rapid burial.

\section{Outer Perimeter Ridge (Sites 875 and 876)}

No clay unit was recovered at either Sites 875 or 876 . At both sites, clasts of altered basalt are reworked into the basal limestone units (Premoli Silva, Haggerty, Rack, et al., 1993, p. 267). This is the only case where underlying material is reworked into the overlying carbonates, suggesting a high-energy depositional regime. At Site 876, some brown to red coloration in the uppermost basalt and in a flowtop breccia indicate subaerial exposure or subaerial eruption, but the lack of a weathered horizon similar to those present at the inner perimeter ridge and platform-interior sites on Wodejebato suggest that subaerial exposure was brief at the outer perimeter sites. Alternatively, a weathering profile at the outer perimeter ridge may have been completely eroded before deposition of the carbonate unit.

\section{Platform Carbonates}

\section{Platform Interior (Site 873)}

The platform carbonate sediments at Site 873 are designated Unit III on Figures 4 and 8 . Two subunits were recognized on shipboard (Premoli Silva, Haggerty, Rack, et al., 1993) in Unit III on the basis of color: Subunit IIIA (58-118 mbsf) is white to very pale brown whereas Subunit IIIB (118-151.5 mbsf) is pale brown to gray. The gray color results from pyrite and organic carbon (Premoli Silva, Haggerty, Rack, et al., 1993, p. 180). Except for color differences caused by pyrite and organic carbon, lithologic variability is less between Subunits IIIA and IIIB than it is within Subunit IIIA. For that reason, Lincoln et al. (this volume) divided Subunit IIIA between Cores 144-873A-5R and $-4 R$ (Figs. 4 and 8). Based on thin-section observations (Lincoln et al., this volume), average fossil abundance is much higher in Subunit IIIA-1 (52\%) than it is below in either Subunit IIIA-2 (32.5\%) or Subunit IIIB 
Hole 877A

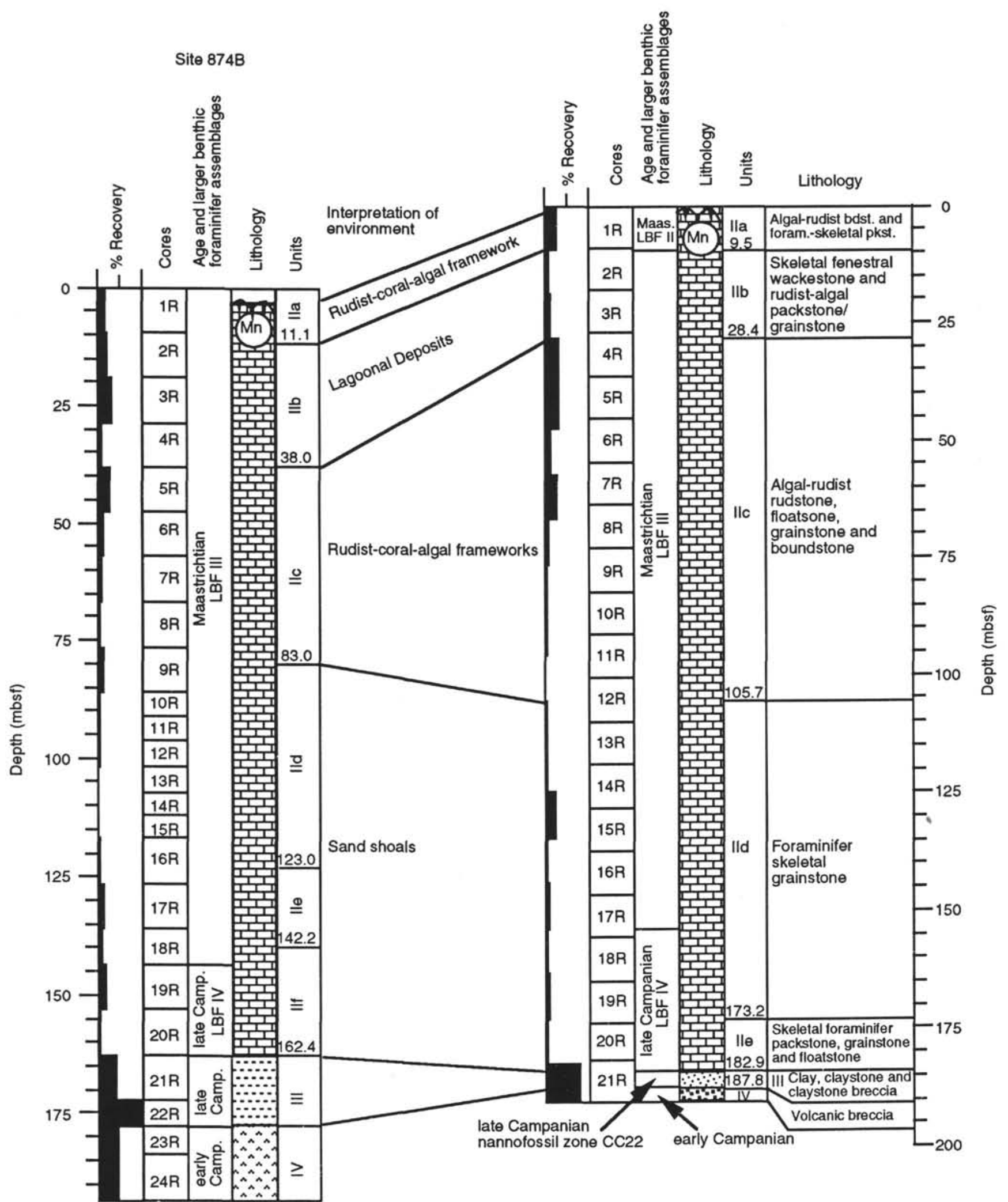

Figure 6. A summary of cored intervals, lithostratigraphy, and biostratigraphic ages for Site 877 is correlated with Site 874 . Both sites are located on the inner perimeter ridge of Wodejebato Guyot. Larger benthic foraminifer (LBF) assemblages are defined in the text. Depositional environment interpretations from Camoin et al. (this volume). The stratigraphic columns are offset based on difference in depth to seafloor at each site. 


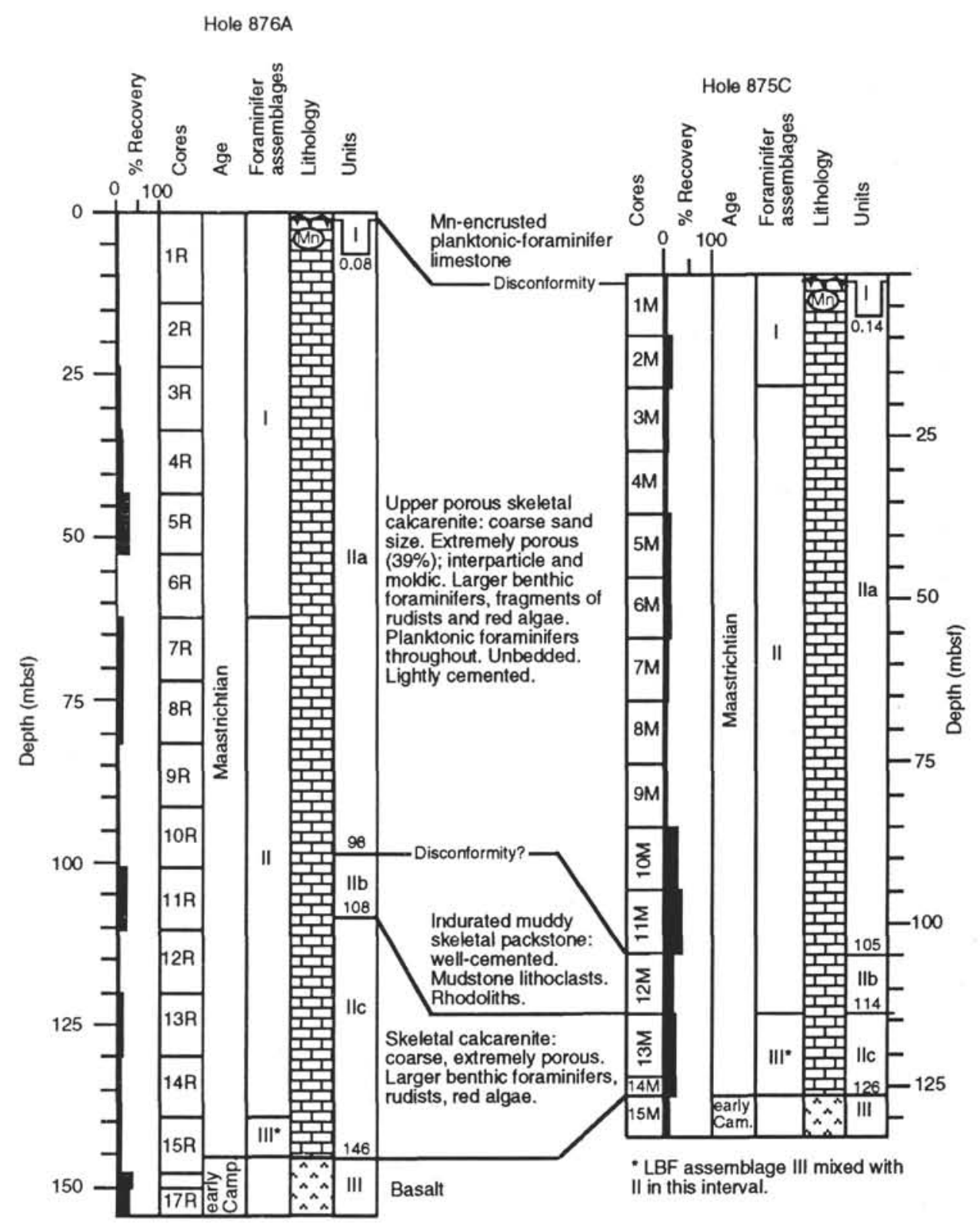

Figure 7. Stratigraphic summary for Sites 875 and 876 (modified from Enos et al., this volume). Larger benthic foraminifer (LBF) assemblages are defined in the text. The stratigraphic columns are offset based on difference in depth to seafloor at each site.

$(39.8 \%)$. The average matrix abundance in Subunit IIIA-2 $(40.3 \%)$ is nearly double the matrix abundance in Subunit IIIB (23\%). Matrix abundance then drops to $11.8 \%$ in Subunit IIIA-1. Cement abundance is highest in Subunit IIIB (19.3\%) and drops to $7.7 \%$ and $7.9 \%$ in Subunits IIIA-2 and IIIA-1, respectively. Porosity, on the other hand increases upward from $4.8 \%$ in Subunit IIIB to $6.8 \%$ in Subunit IIIA-2 to $17 \%$ in Subunit IIIA-1.

Subunit IIIB is dominated by packstones throughout with numerous grainstones and few wackestones. Based on Formation MicroScanner (FMS) images from this hole, these textures may alternate in layers on the order of $10 \mathrm{~cm}$ thick (Lincoln et al., this volume). Most of the matrix-rich textures in Subunit IIIB are transitional between wackestone and packstone. Subunit IIIA-2, on the other hand, is dominated by packstone and wackestone. The abundance of finegrained matrix rises sharply from Subunit IIIB through Subunit IIIA2 and the porosity also increases slightly from the coarser grained Subunit IIIB to the finer grained Subunit IIIA-2; much of the original porosity of Subunit IIIB is filled by equant calcite cement. Cement averages $19.3 \%$ in Subunit IIIB and only $8 \%$ in Subunit IIIA-2.

The depositional textures of Subunit IIIA-1 are similar to those in Subunit IIIB: the subunit is dominated by packstone and grainstone with only a few wackestones identified near the top (Core 144-873B$8 \mathrm{~N})$. Porosity is higher in this subunit (17\%) and cement abundance is lower $(7.9 \%)$ than in Subunit IIIB, even though the depositional textures are comparable. However, the total cement plus porosity is nearly the same (about $25 \%$ ) for Subunits IIIB and IIIA-1, implying that the original porosity of the packstone/grainstone facies in these subunits was about the same. The total cement plus porosity in Subunit IIIA-2 is about $10 \%$ lower than in the other two subunits, indicating a lower original porosity for the matrix-rich facies.

Planktonic foraminifers are very rare in Unit III at Site 873, and they are not age diagnostic. Smaller benthic foraminifers (e.g., small discorbids) and miliolid foraminifers are most abundant in the muddier facies of Subunit IIIA-2. Larger benthic foraminifers are most 


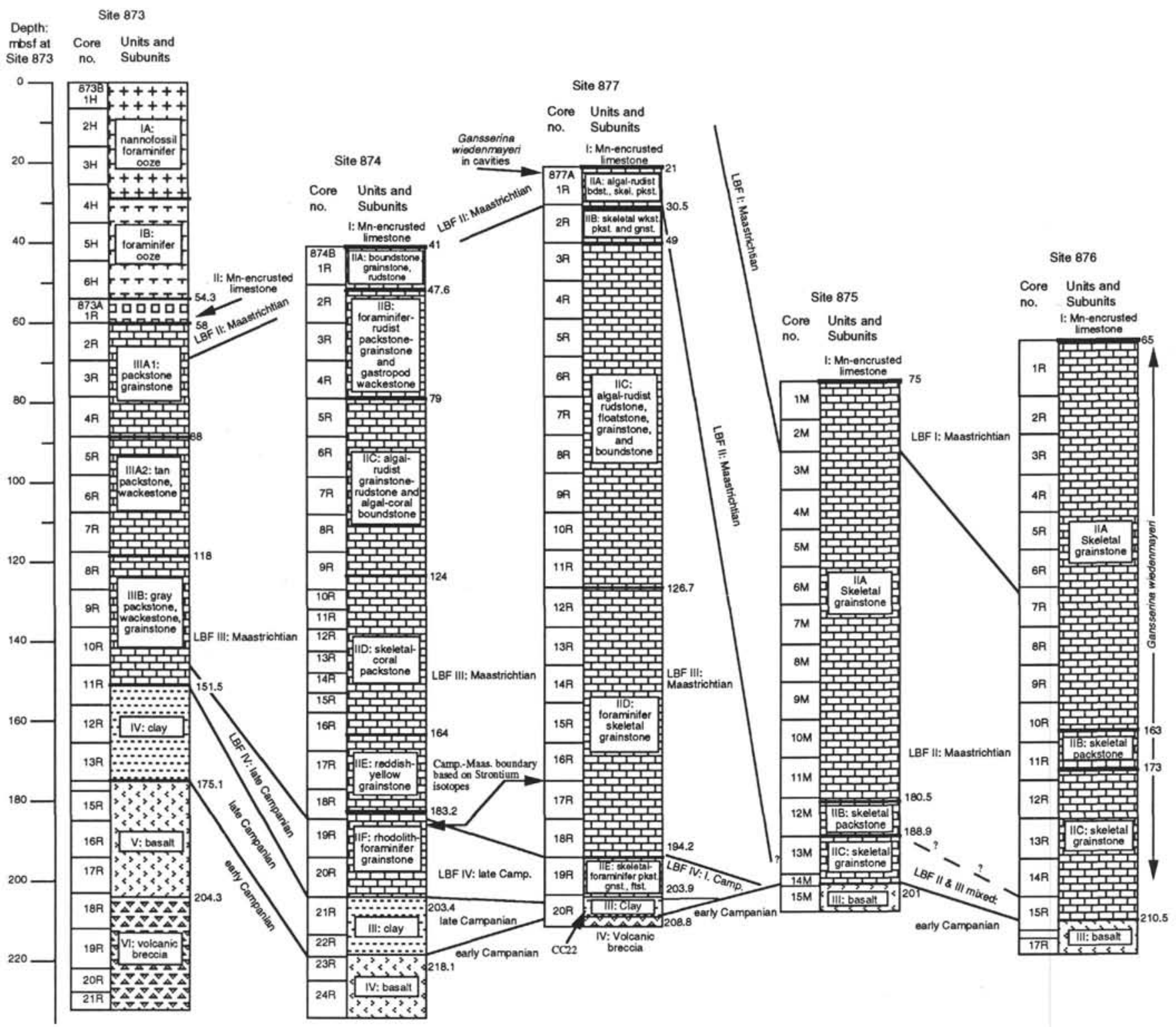

Figure 8. All depths on this composite of the stratigraphic sections drilled on Wodejebato Guyot are meters below the seafloor at Site 873. Subunit numbers and lithologic descriptions are from Lincoln et al. (this volume) for Site 873, Camoin et al. (this volume) for Sites 874 and 877 , and Enos et al. (this volume) for Sites 875 and 876. Larger benthic foraminifer (LBF) assemblages are defined in the text.

abundant in Subunit IIIA-1 as are echinoderm fragments, red algae, and rhodoliths (whole and fragmented). Few coral fragments occur in Subunits IIIA-1 and IIIB. Gastropods, on the other hand, are most abundant (as molds) in Subunit IIIA-2. Bivalve fragments, other than rudists, and radiolitid rudist fragments are ubiquitous throughout. Pellets and peloids are most abundant in Subunit IIIA-2, whereas lithoclasts and intraclasts clasts are more common in Subunits IIIA-1 and IIIB. Pyrite and noncarbonate organic matter is common in the gray Subunit IIIB but virtually absent in Subunits IIIA-2 and IIIA-1.

Bioturbation is prevalent throughout all of the platform carbonates at Site 873, although it is most apparent in the finer grained textures. Coarse/fine laminations, wavy laminae, planar fabric, and imbrication of grains are most common in the grainier packstones and grainstones. Rhizoliths are present near the top of Subunit IIIA-2 (Lincoln et al., this volume). Other associated pores at the top of Subunit IIIA-2 resemble fenestrae. These fenestrae are partly filled with apparent vadose silt. Carbon and oxygen isotope data (Lincoln et al., this volume) for some silts and cements suggest meteoric water may be the origin of some of these features.

Based on geophysical and FMS downhole logs, Unit III at Site 873 (Fig. 4) consists primarily of medium-resistivity lithologies interbedded with distinct, thin beds of medium-high to high resistivity. The higher resistivity interbeds in Subunit IIIB are generally about $10 \mathrm{~cm}$ thick, have sharp bases and sharp or diffuse tops, and occur randomly. These layers are interpreted to be storm beds of grainstone. The higher resistivity (lower porosity) of these storm beds relative to the host wackestone-packstone is the result of preferential precipitation of cement within the initially more porous and storm-winnowed grainstones (Lincoln et al., this volume). The maximum thickness observed for a high-resistivity bed is $0.5 \mathrm{~m}$. Above the basal $9 \mathrm{~m}$ at Site 873 , the frequency of storm beds (high-resistivity layers) decreases upward in Subunit IIIB. This trend may be the result of a general deepening of the depositional environment from the base of Unit III to the top of Subunit IIA-2 and may also be related to 

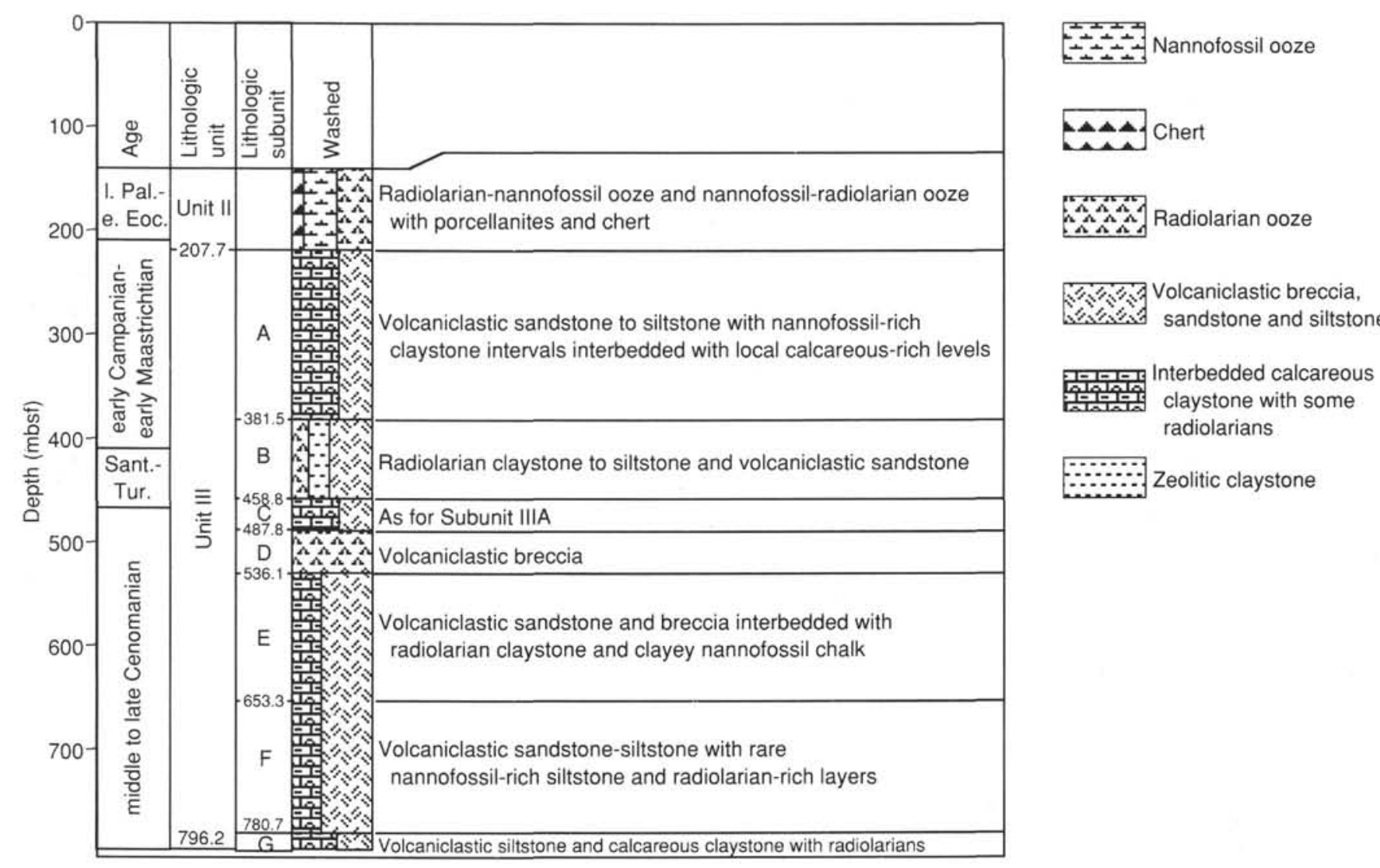

Figure 9. Stratigraphic column for Hole 869B (from Sager, Winterer, Firth, et al., 1993).

aggradation at the inner perimeter ridge as the volcanic edifice subsides. During the initial transgression of the edifice, debris from storms of all sizes may have been able to breach the incipient carbonate platform and leave debris at Site 873. As a more effective barrier grew on the perimeter of the platform only the largest storms would be able to deposit debris in the deepening lagoon.

Unit III has a moderate natural gamma-ray intensity compared with the high gamma-ray intensity of the underlying clay. Based on a comparison of uranium and thorium signals in the gamma-ray spectrum, natural gamma-ray intensity is caused by uranium in Unit III limestones and is caused by thorium in the underlying clay unit (Premoli Silva, Haggerty, Rack, et al., 1993, pp. 192-194). Clay, which could be detected by a thorium signal in the gamma-ray spectrum, apparently is scarce in the lower sediments of the carbonate platform deposited following the initial drowning of the weathered volcanic edifice. The gray Subunit IIIB is relatively enriched in uranium with respect to the overlying tan Subunit IIIA; this result is consistent with the postdepositional reducing (pyrite-precipitating) conditions in Subunit IIIB.

\section{Inner Perimeter Ridge (Sites 874 and 877)}

Three depositional facies have been identified within the carbonate platform at Sites 874 and 877 on the inner perimeter ridge based on integration of core descriptions, thin-section observations, quantitative resistivity measurements, natural gamma-ray intensities, and FMS images (Camoin et al., this volume). The three facies include sand shoals with rhodoliths, algal-coral-rudist framework and associated bioclastic shoals, and lagoonal deposits.

The sand-shoal-with-rhodolith facies comprises Subunits IID to IIF at Site 874 and Subunits IID and IIE at Site 877 (Figs. 5, 6, and 8). This facies is about $80 \mathrm{~m}$ thick at Site 874 and about $77 \mathrm{~m}$ thick at Site
877 and consists primarily of white, pink, yellow, and reddish yellow, fine-grained skeletal packstone and grainstone. Angular to subrounded grains average $0.1-1.5 \mathrm{~mm}$ in size. The sorting, usually poor, may be locally bimodal. These skeletal sands include benthic foraminifers, fragments of red algae, radiolitid rudists, and other bivalves. Coral fragments and rhodoliths, $1.0-1.5 \mathrm{~cm}$ in diameter, are locally common. The facies is finer at the top (more packstones) and coarser at the base (mostly coarse grainstones). Rudists and red algae (including rhodoliths) decrease from the base to the top of the sand-shoal facies at these two sites while the abundance of benthic foraminifers increases from the base to the top. The coloration in these subunits is due primarily to irregularly distributed iron oxides in the matrix and in cavities, which could be the result of slow sedimentation accompanied by oxidation or of pervasive subaerial weathering. Camoin et al. (this volume) report that surficial weathering and "terra rosa" soil development is not supported by petrographic, isotopic, or chemical data. The abundance of algal balls and nodules reported at the base of the inner perimeter ridge carbonate sequence is a common feature in the initial steps of development of Campanian-Maastrichtian carbonate platforms (Camoin et al., 1988) and Cenozoic atolls (Bourrouilh, 1979; Collot, Greene, Stokking, et al., 1991).

Resistivity logs from Site 874 show high to medium resistivity in the basal carbonates of Subunit IIF, followed by monotonously low resistivity throughout Subunits IIE and IID (Fig. 5). Numerous high gamma-ray peaks are evident in Subunit IIF. The co-occurrence of high-resistivity and high gamma-ray peaks in this subunit may be because of condensed sedimentation and/or enhanced cementation (Premoli Silva, Haggerty, Rack, et al., 1993, p. 242) or, as preferred by Camoin et al. (this volume), they may be associated with red algae and rhodolith abundance. High cementation associated with the algal facies may be responsible for the high resistivity. Premoli Silva, Haggerty, Rack, et al. (1993, p. 242) point out that uranium is concen- 
trated in algal-carbonate mats caused by reducing microenvironments (e.g., Serra, 1989) and suggest that perhaps this process may be applicable to red algal concretions; a similar natural gamma (uranium) enrichment was observed in the rhodolith-rich grainstone facies recovered at Site 871 (Premoli Silva, Haggerty, Rack, et al., 1993, p. 83). The frequency and magnitude of gamma peaks decline from the base of the sand shoal facies (Subunit IIF, Site 874) to the top of the sand shoal facies (Subunit IID, Site 874), possibly indicating a decline in the frequency and abundance of beds that are rich in red algae.

A rudist-coral-algal framework and boundstone facies with associated bioclastic shoals make up Subunits IIC and IIA at Sites 874 and 877. Subunit IIC is approximately $45 \mathrm{~m}$ thick at Site 874 and approximately $77 \mathrm{~m}$ thick at Site 877 (Figs. 5 and 6). The depth to the base of the carbonate platform at Sites 874 and 877 , relative to a common reference point, are nearly the same (Fig. 8). The depths to the top of the sand-shoal facies at Sites 874 and 877 are also similar (Fig. 8). However, the depths to the top of this lower "reef" facies at Site 877 is nearly $30 \mathrm{~m}$ higher than at Site 874 , indicating either differential accumulation or differential erosion of this facies. The upper interval of this facies is approximately $6.5 \mathrm{~m}$ thick at Site 874 and about 9.5 $\mathrm{m}$ thick at Site 877.

The lower interval of the rudist-coral-algal facies (Subunit IIC) is comprised of algal-rudist grainstone/rudstone, with a few layers of packstone and algal-coral boundstone. Core recovery and FMS imagery from Site 874 indicate eight cycles with a general "saw-tooth" pattern of upward-increasing resistivity (Fig. 5), which may be caused by gradational transitions from porous grainstone and rudstone to more cemented boundstone. The grainstone/rudstone and packstone/floatstone in Subunit IIC are medium to coarse grained, poorly sorted and contain radiolitid and caprinid rudist fragments, red algae, and benthic foraminifers. Red algae may locally encrust large skeletal pieces, forming rhodoliths. At Site 874 the boundstone layers of this facies are dominated by tabular coral colonies and a few stromatoporoids. At Site 877 , rudists form the bulk of the organic framework. Radiolitids dominate in the lower portions of Subunit IIC, whereas caprinid rudists, up to $6 \mathrm{~cm}$ in diameter, dominate the upper portion of the subunit. Algal boundstones are most abundant at the base of Subunit IIC in Hole 877, suggesting that these organisms may have played a role in stabilizing the underlying mobile sand shoal.

The skeletal grainstone and rudstone associated with the algalcoral-rudist framework-boundstone facies in Subunit IIA at Sites 874 and 877 (Figs. 5 and 6) is generally poorly sorted, medium, coarse, and very coarse grained, with only a few occurrences of packstone at Site 877 . These grainstone and rudstone deposits contain fragments of caprinid and radiolitid rudists, hexacorals and octocorals, calcareous sponges, and red algae. The large skeletal fragments are commonly micritized and contain millimeter-sized borings. Benthic foraminifers are moderately abundant. The boundstone/framestone in Subunit IIA at Sites 874 and 877 consists of laminar colonies of octocorals and hexacorals, radiolitid and caprinid rudists, and clumps of solenoporaceans that are heavily encrusted by corallinaceans and to a lesser extent by foraminifers.

The coarse grain size and evident abrasion of the bioclastic debris associated with the framestone and boundstone suggests a high-energy environment. Based on the sawtooth pattern on the resistivity logs discussed above, the rim of Wodejebato Guyot apparently grew by repeated deposition of bioclastic debris that was then colonized by framework and boundstone builders. The composition of the debris is similar to the framework-boundstone deposits, suggesting the debris was produced locally, probably by erosion of adjacent frameworks. There is a general trend at both sites from coral-algal boundstones at the base of Subunit IIC to radiolitid-rudist assemblages, then to caprinid-rudist assemblages toward the top of Subunit IIC. This trend may represent a biotic succession or a change in environmental conditions. The dominance of recumbent caprinid rudists may be related to their better adaptability to high-energy environments and unsuitable substrates, such as abundant shifting sands, where exposure of hard surfaces for attachment is likely to be limited (Skelton, 1979; Camoin et al., 1988). Algal-coral boundstone dominates in Subunit IIC at Site 874 whereas rudist communities are more common at Site 877 . This change between the sites may result from their positions relative to the crest of the inner perimeter ridge. Coral communities may have been more common at the slightly seaward location of Site 874 , whereas rudists were more common at the more sheltered position of Site 877 .

The third facies recognized by Camoin et al. (this volume) is a lagoonal facies represented by Subunit IIB at Sites 874 and 877 . This facies is $31.5 \mathrm{~m}$ thick at Site 874 and $19 \mathrm{~m}$ thick at Site 877 ; it is characterized by poorly sorted, very pale brown to white, skeletal grainstone, packstone, and floatstone or pinkish gray, burrowed dolomitic wackestones. Contacts between the grainier textures and muddier textures appear to be a unconformable with borings, local erosion, and reworking of intraclasts. The resistivity and FMS logs indicate beds of high resistivity (probably the packstone and floatstones) alternating with beds of low resistivity (probably wackestones and packstones that have high moldic porosity after gastropods). Miliolids, rotalids, and discorbids dominate the benthic foraminifer assemblages. Micritized fragments of leached gastropods, rudist fragments (radiolitid and caprinid), and other bivalves are common. The micrite matrix is locally peloidal and may display a geopetal distribution in intergranular pores. The dolomitic wackestone beds are characterized by abundant fenestrae that locally form irregular networks of vertically elongated canals reminiscent of fluid-escape structures. Skeletal abundance is low and is dominated by small gastropods, benthic foraminifers (mostly miliolids), smooth-shelled ostracodes, green algae, and few abraded fragments of coral, red algae, and rudists. Undulating laminations may be formed by algal mats. Both fossil content and sedimentologic criteria indicate a low-energy, shallow-marine environment. Short-lived periods of emergence may be indicated by the dolomitization of the wackestone beds, dissolution of shell material, and local reworking of lithoclasts. The paucispecific assemblage of very small foraminifers, smooth-shelled ostracodes, and cerithid gastropods may indicate temporary episodes of unfavorable ecologic conditions such as low illumination, low oxygenation, temperature fluctuations, or poor nutrient availability. The skeletal packstone and wackestone beds with abraded bioclasts that alternate with the wackestones are most likely washovers or storm beds transported from the outer shoals of the guyot.

\section{Outer Perimeter Ridge (Sites 875 and 876)}

Three subunits are recognized in the limestones cored at Sites 875 and 876 on the outer perimeter ridge of Wodejebato Guyot (Enos et al., this volume; Figs. 7 and 8). A lower porous skeletal calcarenite (Subunit IIC) overlies the basalt described above. This skeletal grainstone and packstone with extensive moldic porosity is $12.1 \mathrm{~m}$ thick at Site 875 and $37.5 \mathrm{~m}$ thick at Site 876 . The grain size is coarse sand, and sorting is generally good. The dominant skeletal components include larger benthic foraminifers; mollusk fragments, including abundant rudists; red algae; and echinoderm fragments. Minor components are corals, ostracodes, and planktonic foraminifers. Interparticle and moldic porosity is very high throughout this subunit.

Subunit IIB, the middle indurated muddy skeletal packstone, is only 8.4 and $10 \mathrm{~m}$ thick at Sites 875 and 876 , respectively. Slower drilling rates indicate greater lithification in this subunit relative to the adjacent calcarenites. Packstones are more abundant in this subunit than they are in the calcarenites. The major skeletal constituents are similar to those of the calcarenite subunits, except for an abundance of rhodoliths. Mud content is significantly higher in Subunit IIB than in the calcarenite subunits, and porosity is appreciably less. Cement is also more abundant in Subunit IIB relative to the calcarenite subunits. In contrast to the coarser, well-sorted calcarenite subunits, some sedimentary structures are visible in Subunit IIB. Distinct burrows were noted at several intervals, and one peloidal packstone has millimeter-scale cross-laminations dipping $8^{\circ}-10^{\circ}$. Enos et al. (this vol- 
ume) identified a scalloped lithologic contact having $1 \mathrm{~cm}$ of relief, suggesting dissolution of grains beneath the contact. Two intervals of well-cemented skeletal lithoclasts in rudstone at the base of the overlying calcarenite suggests that the top of Subunit IIB may have been lithified before deposition of the overlying sands. One pebble of wackestone described by Enos et al. (this volume) contains a contact between a gastropod wackestone and a skeletal packstone typical of Subunit IIB. The wackestone is discolored at the contact. The surface of the wackestone is ragged and truncates grains. A small vug within the wackestone is filled with the surrounding skeletal packstone. Enos et al. (this volume) interprets the wackestone as a lithoclast that was lithified and leached to form molds and vugs before deposition with the skeletal sand of the packstone. A large piece of gastropod mudstone recovered from Subunit IIB contains large ovoid cavities filled with packstone; this may also be a lithoclast with large vugs that was deposited in the packstone sands.

Subunit IIA at Site 875 and 876 is another interval of porous skeletal calcarenite that consists of white, highly porous, lightly cemented, skeletal packstone and grainstone. This subunit is 105.5 and $98 \mathrm{~m}$ thick at Sites 875 and 876 , respectively. The dominant skeletal constituents are the same in Subunit IIA as in Subunit IIC with the exception that corals are about three times as abundant in Subunit IIA ( $6.4 \%$ for Subunit IIA compared with $2 \%$ for Subunit IIC). The porosity of the subunit is $39.4 \%$ based on 22 analyses, compared with $30.9 \%$ in Subunit IIC (Enos et al., this volume).

\section{Post-drowning Facies}

The limestone units at all sites drilled during Leg 144 are encrusted by laminated, dense, ferro-manganese crusts, up to $3 \mathrm{~cm}$ thick. The encrusted limestone and skeletal fragments are commonly phosphatized. At Site 873 , the drowning facies is represented by manganese-coated, phosphatized lithoclasts in a planktonic foraminifer matrix. The lithoclasts include large bioclasts, such as fragments of radiolitid rudist, and skeletal grainstones and rudstones with abundant rudist fragments, larger benthic foraminifers, and red algae. Lincoln et al. (this volume) report that a sample of cement from within one of the manganese-coated skeletal grainstone clasts from Site 873 (Sample 144-873B-8N-1, 4-7 cm) has a slightly negative carbon isotopic composition $(-0.14 \%)$ and a very negative $(-7.8 \%$ ) oxygen isotopic composition. The negative carbon values and very negative oxygen values could indicate exposure of the limestone to meteoric waters before drowning, erosion, and encrustation by ferro-manganese oxides. Additional isotopic evidence for the possible exposure of the underlying limestones to meteoric waters is discussed further in Lincoln et al. (this volume). A single blade of clear calcite sitting in a manganese-oxide-encrusted mollusk mold that is partly filled by Tertiary planktonic foraminifers (Sample 144-873A-1R-1, 0-3 cm) has an isotopic composition typical of cold marine waters (positive oxygen and carbon); this cement is similar in isotopic composition to cements in limestones dredged from the sides of other guyots in the Marshall Islands (Lincoln, 1988) and is similar to cements from Site 877 that have been identified petrographically as deeper marine in origin (Opdyke et al., this volume). This cement most likely formed following submergence of the guyot well below sea level.

At Site 874 and 877 , the contact between the ferro-manganese oxide crusts and the underlying foraminifer rudist grainstone is scalloped and displays multiple generations of borings. At Site 876 on the outer perimeter ridge, a large cylinder of core was recovered (interval $144-876 \mathrm{~A}-1 \mathrm{R}-1,22-41 \mathrm{~cm}$ ) in which a vertical, manganese-stained contact extends from near the top of the piece at $0.25 \mathrm{mbsf}$ to $0.39 \mathrm{mbsf}$ where it flattens and passes out of the core (Premoli Silva, Haggerty, Rack, et al., 1993, p. 266; Fig. 9). Maastrichtian skeletal packstone with phosphatized matrix and patchy manganese stain is in vertical contact with lithified pelagic limestone. No unequivocal borings, truncated grains, or skeletal encrustations are evident on the contact, but its vertical orientation requires that the packstone was lithified and eroded before deposition of the pelagic sediments (Enos et al., this volume). Pelagic mud (Eocene age; Watkins et al., this volume) fills the interparticle pore space of the packstone and a few skeletal molds near the contact. At all sites, ferro-manganese oxide dendrites commonly permeate the overlying or surrounding pelagic sediments. The pelagic limestone consists of planktonic foraminifers, nannofossil mud, and bioclasts such as rudist fragments reworked from the underlying limestone. Pores between the ferro-manganese crusts are filled with at least four generations of pelagic sediments that range in age from late Paleocene to mid Eocene (Watkins et al., this volume).

\section{Diagenesis}

Enos et al. (this volume) presents a detailed diagenetic synthesis for the five holes drilled on Wodejebato Guyot. What follows is a brief summary of the principle observations and conclusions presented by Lincoln et al. (this volume), Camoin et al. (this volume), and Enos et al. (this volume) for the platform interior site, the inner perimeter ridge, and the outer perimeter ridge, respectively.

\section{Platform Interior (Site 873)}

The majority of fossil components from Site 873 have oxygen isotopic compositions between $-5 \%$ and $0 \%$ and carbon isotopic compositions between $3 \%$ and $0 \%$ (Lincoln et al., this volume). The majority of micritic matrix samples fall in the same range as the fossil components. These isotopic compositions are consistent with studies of reef and lagoonal sediments from modern atolls in the Marshall Islands (Gross and Tracey, 1966; Gonzalez and Lohmann, 1985). The majority of cements are clear, equant to bladed, lining or filling molds and intergranular pore space, with carbon isotopic compositions ranging from $2 \%$ to $3 \%$ and oxygen isotopic compositions from $-1 \%$ to $0 \%$. These are typical values for marine cements forming at temperatures of $12^{\circ}-20^{\circ} \mathrm{C}$.

Five fossil samples, three matrix samples, and two cements have carbon and oxygen isotopic compositions more typical of meteoric diagenesis (i.e., negative carbon and oxygen values; Land, 1970; Land and Epstein, 1970). Except for one matrix sample from interval 144$873 \mathrm{~A}-9 \mathrm{R}-2,23-28 \mathrm{~cm}$, which has a carbon isotopic composition of $-0.11 \%$, all of the samples with negative carbon isotopic values come from the very top of Subunit IIIA-2 and from throughout Subunit IIIA-1. The fine-grained matrix from a sample with rhizoliths and possible vadose silt (Sample 144-873A-5R-1, 23-26 cm) has a carbon isotopic composition of $-0.83 \%$. This composition supports petrographic evidence for subaerial exposure at the top of Subunit IIIA-2.

In Sample 144-873B-10N-1, 67-69 cm (Subunit IIIA-1), micritic grain coatings have a positive carbon $(1.46 \%)$ and a negative oxygen $(-3.06 \%)$ isotopic composition, characteristic of the normal shallowmarine environment. However, an orbitoid foraminifer and red algae from this sample have negative carbon $(-1.38 \%$ and $-0.38 \%$, respectively) and very negative oxygen ( $-5.39 \%$ and $-4.04 \%$, respectively) isotopic compositions. Although meniscus cements surrounding these components have a positive carbon composition $(0.78 \%$ ) they do not plot with other cements from Site 873 . This is one of only a few cements with carbon values less than $1 \%$ and oxygen composition less than $-2 \%$. Several rudist fragments, red algal grains, and coarse, isopachous pore-filling cements all have negative carbon compositions and oxygen compositions lighter than $-4 \%$. These light carbon and oxygen isotopic compositions of Subunit IIIA-1 components may suggest either that parts of the subunit are supratidal, coarse sand deposits and that the meteoric alteration took place before burial or that the entire subunit was exposed to meteoric conditions, following original burial, during a eustatic lowstand.

\section{Inner Perimeter Ridge (Sites 874 and 877)}

In general, the sediments of the inner perimeter ridge still exhibit a high percentage of open porosity. On the inner perimeter ridge, the 
sediments are strongly cemented in the top of the carbonate sequence (Subunits IIA and IIB as well as the top of Subunit IIC at Sites 874 and $877)$. Porosity in these upper cores ranges from $1 \%$ to $10 \%$. The original porosity is filled by multiple generations of banded cements up to $1 \mathrm{~mm}$ thick. The typical sequence of cements in these cores starts with isopachous fringes of amber to brownish, radiaxial to fascicularoptic calcites with sweeping extinction and equant, bladed and fibrous morphologies. These cements are zoned by variations in inclusion density and become inclusion free in the outermost zone. The crystals become wider away from cavity walls and may display a botryoidal habit in large intergranular cavities. These cements only fill syndepositional primary porosity and are completely absent in secondary porosity, especially molds. Prismatic to scalenohedral inclusion-free calcites may overgrow some radiaxial to fascicular-optic calcites. Translucent scalenohedral to equant blocky calcite cements fill chambers of foraminifers and some cavities in the overlying pelagic sediments. These cements may also cut the isopachous fringes of fascicular-optic calcitic cements. The stable carbon and oxygen isotopic compositions of the radiaxial and fascicular optic calcites average $2.34 \%$ for $\delta^{13} \mathrm{C}$ and $-0.83 \%$ for $\delta^{18} \mathrm{O}$. These stable isotope compositions and the petrographic observations support precipitation penecontemporaneous with deposition in a shallow-marine environment. The isotope compositions from these cements are similar to those reported from radiaxial and fascicular-optic cements in the Bahama Escarpment (FreemanLynde et al., 1986) and the Miocene of Anewetak Atoll (Saller, 1986). The average $\delta^{13} \mathrm{C}$ and $\delta^{18} \mathrm{O}$ compositions for the scalenohedral cements are $2.22 \%$ and $-1.03 \%$, respectively. The average $\delta^{13} \mathrm{C}$ and $\delta^{18} \mathrm{O}$ compositions for the blocky calcites are $1.46 \%$ and $-1.62 \%$, respectively.

Former aragonitic skeletons (corals, rudists, and gastropods) exhibit differential preservation throughout the carbonate sequence on the inner perimeter ridge. Coral and gastropod skeletons are either totally replaced by blocky calcite or dissolved and preserved only as micrite envelopes. In the lower skeletal shoals facies, the porosity is high with vuggy, moldic, and solution-enlarged interparticle porosity common. These sediments are poorly lithified, although isopachous crusts of equant calcite cements may line intraskeletal and interskeletal pores. The fragile pore network in the lower sand shoal facies could only have developed in situ by dissolution in either meteoric or undersaturated deeper marine waters. Irregular solution cavities, up to $1 \mathrm{~cm}$ in size, occur in the lagoonal facies of the inner perimeter ridge and in the underlying reef facies. Intervals near the top of the inner perimeter ridge contain rudist shell fragments that exhibit a gradational transition from fully preserved aragonitic parts to parts totally replaced by clear, blocky calcite. The isotopic composition of the well-preserved rudists average $4.53 \%$ for $\delta^{13} \mathrm{C}$ and $-1.11 \%$ for $\delta^{18} \mathrm{O}$. Isotopic composition of inclusion-rich calcites with relics of aragonite texture average $2.46 \%$ for $\delta^{13} \mathrm{C}$ and $-0.48 \%$ for $\delta^{18} \mathrm{O}$; isotopic composition of inclusion-free calcites with no relics of aragonite texture average $1.21 \%$ for $\delta^{13} \mathrm{C}$ and $-7.06 \%$ for $\delta^{18} \mathrm{O}$. These shifts in isotopic composition indicate replacement by solution-reprecipitation. The aragonite to calcite transition may have occurred in waters that were depleted in ${ }^{18} \mathrm{O}$ and ${ }^{13} \mathrm{C}$, possibly in meteoric waters (e.g., Sandberg and Hudson, 1983; Al-Aasm and Veizer, 1986).

\section{Outer Perimeter Ridge (Sites 875 and 876)}

The cements in the lower porous skeletal calcarenite of Sites 875 and 876 are finely crystalline, bladed crusts of calcite with acute pyramidal terminations and uniform extinction (Enos et al., this volume). This is the dominant cement throughout the outer perimeter ridge. Less common is medium crystalline, equant calcite that forms syntaxial overgrowths on mollusks, foraminifers, and echinoderms. The cement is confined to intergranular pores. The initial cement in at least four samples from Hole 876A is an isopachous crust of cloudy, fibrous calcite with sweeping extinction characteristic of radiaxial calcite. The only cement in most other samples is medium crystalline, limpid, bladed crystals with uniform extinction. These are nearly identical to the cements that dominate in the rest of the outer perimeter ridge. In the upper porous skeletal calcarenite, the very finely to medium crystalline crusts of limpid, bladed calcite is just sufficient to weld grains together at their contacts.

\section{RESULTS FROM SITE 869}

Site 869 , situated $83 \mathrm{~km}$ southwest of Pikinni Atoll and Wodejebato Guyot was drilled during ODP Leg 143 (Sager, Winterer, Firth, et al., 1993). The location of the site, $11^{\circ} 00.09^{\prime} \mathrm{N}, 154^{\circ} 45.02^{\prime} \mathrm{E}$, was close enough to receive sediments shed by these two edifices (Fig. 1). Drilling at this site penetrated $588.5 \mathrm{~m}$ of middle-upper Cenomanian to upper Campanian-lower Maastrichtian volcaniclastics interlayered with nannofossil and radiolarian claystone (Fig. 9). The gray to green volcaniclastic sandstones and breccias contain sparse carbonate debris that was derived from a nearby shallow-water carbonate platform. These volcaniclastics are overlain by $67.7 \mathrm{~m}$ lower Paleocene to upper Eocene radiolarian-nannofossil ooze and nannofossil-radiolarian ooze with porcelainites and chert that, in turn, are overlain by $88.2 \mathrm{~m}$ upper Eocene to lower Miocene clayey nannofossil ooze and radiolarian nannofossil ooze.

Deposition of volcaniclastics at Site 869 began in mid to late Cenomanian time; the base of the volcaniclastics was not recovered. The oldest rocks recovered at Site 869 consist of dark-colored volcaniclastic sandstones to siltstones that also contain pelagic nannofossils and radiolarians (Subunits IIIG and IIIF; Fig. 9). These rocks are devoid of any shallow-water debris; sedimentary structures indicate deposition by turbidity currents. These sandstones and siltstones (115.9 m thick) are overlain by $117.2 \mathrm{~m}$ of volcaniclastic sandstone and breccia interbedded with radiolarian claystone and clayey nannofossil chalk (Subunit IIIE; Fig. 9). Orbitolinid foraminifers, ooids or oolitic limestone, and coalified woody fragments indicate the presence of one or more emergent islands with fringing reefs or carbonate-producing platforms. The uppermost Cenomanian deposits at this site consist of $48.7 \mathrm{~m}$ of coarse, poorly sorted basaltic breccias (Subunit IIID; Fig. 9). Sager, Winterer, Firth, et al. (1993) suggest that the fine-grained, aphyric texture of the basalt fragments, as well as the abundance of glass shards, implies that some of the basalt erupted at considerable water depth (Sager, Winterer, Firth, et al., 1993, p. 312). Before the Cenomanian/Turonian boundary at Site 869, the deposition of volcanic breccia ceased and deposition of $29 \mathrm{~m}$ of turbidite volcaniclastic sand and silt commenced and continued through this boundary (Subunit IIIC; Fig. 9). This change in sedimentation may indicate a shift from proximal to distal fan deposition that could be related to a Cenomanian-Turonian eustatic rise that flooded the sediment source and/or to the waning or cessation of nearby volcanism (Sager, Winterer, Firth, et al., 1993). The carbonate debris in this interval contains orbitolinid foraminifers and micritic, concentrically layered "deeper water" ooids that are consistent with an open marine, possibly off-bank, source area.

Subunit IIIB (Fig. 5) consists of $77.3 \mathrm{~m}$ of radiolarian claystone to siltstone with redeposited volcanic sands and some shallow-water carbonate material that spans Turonian to early Campanian. Deposition of volcaniclastic sandstone and siltstone by turbidity currents with claystone intervals recommenced from early-mid Campanian through early Maastrichtian (Subunit IIIA; Fig. 9). The shallow-water carbonate debris deposited with the uppermost volcaniclastics consists of bivalve, echinoid, and red-algal fragments as well as orbitoid foraminifers; an assemblage similar to that recovered in the carbonate platform sediments of Wodejebato Guyot during Leg 144.

Basalt clasts recovered from the Cenomanian volcaniclastic turbidites at Site 869 have been dated by the ${ }^{40} \mathrm{Ar} /{ }^{39} \mathrm{Ar}$ method at $95-93$ $\mathrm{Ma}$ (Pringle et al., this volume).

\section{BIOSTRATIGRAPHY}

Thin, black, calcareous claystone layers that underlie the carbonate platform units at Sites 873,874 , and 877 contain sparse but well- 
preserved nannofossil assemblages that indicate a Campanian age. The richest nannofossil assemblage from the clay unit at Site 877 (interval 144-877A-20R-1, 42-45 cm) indicates Zone C22 of late Campanian age (Erba et al., this volume). The clay unit at this site also contains reworked calcareous nannofossils that are Cenomanian in age (Premoli Silva, Haggerty, Rack, et al., 1993, p. 298). The clay horizon is absent at Sites 875 and 876 , as are the Campanian nannofossils.

The biostratigraphy of the carbonate platform relies primarily on larger benthic foraminifer (LBF) assemblages. The following summary is based on Premoli Silva et al. (this volume). The oldest assemblage (late Campanian), Pseudorbitoides cf. trechmani without Sulcoperculina and Asterorbis (LBF Assemblage IV in Figs. 4-8), is present at the base of Sites 873,874 , and 877 , but is absent at Sites 875 and 876. Pseudorbitoides $\mathrm{cf}$. trechmani with Sulcoperculina and Asterorbis (LBF Assemblage III in Figs. 4-8) appears at the top of Cores 144-873A-11R and 144-874B-19R and in Core 144-877A-18R. Strontium isotope values characteristic of Maastrichtian time occur from the top of the carbonate platform to a depth of 145 mbsf at Site 874 (Wyatt et al., this volume) and to a depth of 154 mbsf at Site 877 (Wilson et al., this volume). These depths are interpreted as the Campanian/Maastrichtian boundary at Sites 874 and 877 . The entire interval containing LBF Assemblage III at Site 874 occurs above this Campanian/Maastrichtian boundary. The Campanian/Maastrichtian boundary inferred from strontium isotopes at Site 877 falls within the interval containing LBF Assemblage III. The Pseudorbitoides cf. trechmani with Sulcoperculina and Asterorbis assemblage is present at Sites 875 and 876. It is mixed, however, with Omphalocyclus (younger); therefore, it is probably transported at these sites. Omphalocyclus associated with Sulcoperculina and Asterorbis (LBF Assemblage II in Figs. 4-8) appears in Cores 144-873B-10N, 144-877A-1R, 144-875C-12M, and 144-876B-14R. Omphalocyclus is considered to be Maastrichtian. The uppermost portions of Sites 875 and 876 , from Core 144-875C-2M and from the top of Core 144-876B-7R, are devoid of Sulcoperculina. Omphalocyclus without Sulcoperculina is listed as LBF Assemblage I in Figures 4-8. Sulcoperculina occurs through the topmost layers of Sites 873,874 , and 877 . This could indicate that the uppermost portions of the outer perimeter ridge sites are younger than the top of all other sites on Wodejebato.

Rudist assemblages from all sites also indicate a CampanianMaastrichtian age (Camoin et al., this volume).

Planktonic foraminifers occur throughout Sites 875 and 876 . They are present but generally rare at the other three sites. Most of the planktonic foraminifers are long-ranging Campanian Maastrichtian species. Gansserina wiedenmayeri ( $G$. gansseri gr.) occurs at the top of Hole $877 \mathrm{~A}$ and is also frequent at Site 876 from Core 144-876B$14 \mathrm{R}$ to the top. At the top of Hole $877 \mathrm{~A}$, planktonic foraminifers appear to have filtered into voids following drowning of the edifice whereas at Site 876, planktonic foraminifers were deposited coeval with the skeletal sands. This would indicate that Site 877 (the inner perimeter ridge) may have drowned before or during deposition at Site 876. G. wiedenmayeri ranges from the G. gansseri Zone to the lower part of the A. mayaroensis Zone, or from early Maastrichtian to early late Maastrichtian. The occurrence of $G$. wiedenmayeri in voids at Site 877 indicates drowning before or slightly later than $68 \mathrm{Ma}$ (beginning of A. mayaroensis Zone).

\section{INTERPRETATION: GEOLOGIC HISTORY OF WODEJEBATO GUYOT}

\section{Formation of the Volcanic Edifice}

Based on drilling at Site 869 , it is apparent that either Wodejebato or Pikinni was erupting subaerially during middle to late Cenomanian time. Reworked Cenomanian nannofossils recovered at the base of Site 877 on Wodejebato Guyot indicate that this edifice formed during or before Cenomanian time and therefore is a likely source of the volcaniclastic sediment recovered at Site 869. Although the abundance of aphyric lavas and glass shards in some intervals of the Cenomanian volcaniclastics at Site 869 may indicate submarine eruption, the presence of coalified woody material and carbonate debris characteristic of shallow water in these same deposits indicates that an edifice, possibly Wodejebato, grew into the photic zone and produced one or more volcanic islands before the end of Cenomanian time.

The edifice supplying sediment to Site 869 apparently was submerged and quiescent from latest Cenomanian to early Campanian time based on the slower sedimentation rates and the prevalence of redeposited volcaniclastic material within intervals of this age at apron Site 869 (Fig. 9). If eruptions ceased on Wodejebato and subsidence began before the end of Cenomanian time, a sea-level rise at the Cenomanian/Turonian boundary (e.g., Schlanger, 1986) may have drowned the summit of the edifice. Reworked nannofossils recovered at the base of Site 877 indicate that the guyot may have already been submerged in late Cenomanian time. Planktonic foraminifers in limestones dredged from the flanks of Wodejebato Guyot suggest that the edifice was submerged in Santonian to earliest Campanian time (Lincoln et al., 1993).

A second pulse of rapid volcaniclastic deposition began in the early Campanian at Site 869 . These volcaniclastic deposits are roughly coeval with the eruption of lavas and the formation of volcanic breccias at Sites 873-877 on Wodejebato. Based on these observations, Wodejebato underwent two eruptive phases separated by about 10 m.y. of relative quiescence. The late Cenomanian nannofossils redeposited within late Campanian clays at Site 877 may be explained by the following sequence of events: the nannofossils were first deposited when the edifice drowned during a late Cenomanian eustatic rise combined with subsidence following a mid-late Cenomanian eruptive cycle. When Wodejebato was uplifted again during eruptions in the Campanian, the nannofossil-bearing sediments could then be eroded and redeposited at Site 877.

At least two early Campanian eruptive phases, each followed by a period of subaerial weathering, are recorded at drill sites on Wodejebato Guyot. We say "at least" because Leg 144 never drilled beneath the Campanian volcanics into the older volcanics that should be present based on results at Site 869 . Submarine, possibly near-shore, phreatomagmatic eruptions of vesicular basalt formed the hyaloclastic debris flows of Unit VI at Site 873. Debris flows directed outward from a central eruption site may have produced the outward-dipping deep seismic reflectors that appear to underlie the carbonate platform at Wodejebato Guyot (Fig. 2). A period of weathering in a subaerial environment oxidized at least the upper $5 \mathrm{~m}$ of the hyaloclastic debris. A second early Campanian episode of eruption deposited at least eight olivine-poor alkalic basalt and hawaiite flows. They represent the last volcanic episode at this site and probably the waning stages of volcanism for the entire edifice.

\section{Weathering of the Volcanic Edifice}

The eruption of basalts was followed by a period of weathering presumed to be subaerial because of the presence of oxidation products in the clay horizons at Sites 873,874 , and 877 . This weathering stage produced a weathering profile at least $23.6 \mathrm{~m}$ thick at Site 873 before subsidence into the marine realm. The mineralogy of these clays, kaolinite, goethite, and hematite, as well as the thickness of the soil profile, suggests development in an upland region (Holmes, this volume). Poorly drained soils would produce smectites and a thinner weathering profile. The black clay layers that cap the clay units at Sites 873,874 , and 877 have elevated total organic carbon and total sulfur relative to the underlying clays. Based on isotopic ratios, the sulfur is probably the result of sulfate reduction as marine waters flooded organic rich clays (Buchardt et al., this volume).

\section{Subsidence of the Volcanic Edifice}

Following mid-plate volcanism, which interrupts normal thermal subsidence of the lithosphere with uplift because of reheating and 
perhaps upward-directed forces, the plate surrounding a volcanic edifice begins to subside at a rate typical of younger and shallower seafloor. The apparent "younger" age of the lithosphere surrounding a volcanic edifice following eruption is the "thermal reset age." Two methods can be used to calculate the thermal reset age. One uses paleodepth at the time of eruption, which can be approximated by the current elevation of the guyot above surrounding seafloor, to determine apparent age of the lithosphere from a depth versus age model for oceanic lithosphere (e.g., Parsons and Sclater, 1977). The second method matches the rate of subsidence, calculated from either the sedimentation rate or from the current depth of the guyot below sea level and the age of drowning, to a seafloor subsidence curve to find the thermal reset age. Using these methods, Larson et al. (this volume) estimate a thermal reset age for Wodejebato Guyot of 29 m.y. This means that following eruption, Wodejebato subsided as if it was sitting on normal 29 m.y. lithosphere. Based on the gap in ages between the youngest eruptive phase (about $83 \mathrm{Ma}$, early Campanian) and the oldest marine sedimentation following this eruption (about $76 \mathrm{Ma}$, late Campanian, nannofossil Zone C22 at Site 877), it took nearly $7 \mathrm{~m}$.y. for the volcanic edifice to subside below sea level. Using the Parsons and Sclater's (1977) thermal subsidence curve and the Larson et al. (this volume) thermal reset age of 29 m.y., the volcanic edifice had to subside over $200 \mathrm{~m}$ before marine sedimentation began at any of the sites drilled. By $76 \mathrm{Ma}$ the effective thermal age of the lithosphere was about 36 m.y. (thermal reset age of 29 plus 7 m.y.). Based on the Parsons and Sclater (1977) model, the subsidence rate for lithosphere of this age, and thus the subsidence rate at the time carbonate sedimentation began, was about $29 \mathrm{~m} / \mathrm{m}$.y.

\section{Development of the Carbonate Platform}

\section{Late Campanian Initial Transgression}

Wodejebato subsided in early to mid-Campanian time resulting in a transgression that flooded the volcanic edifice that sloped gently away from a central volcanic island. The first marine deposits at Sites 875 and 876 are substantially younger than most of the carbonate sediments deposited at Sites 873,874 , and 877 , yet the initial transgression should have flooded the outer perimeter ridge first. If late Campanian deposits were laid down at the outer perimeter ridge sites during the initial transgression, they were eroded during a subsequent sea-level fall or by submarine erosion. It is also possible that the highenergy, seaward position of the outer perimeter ridge sites may have prevented accumulation of sediment until later in the guyot's development. The first marine deposits on the inner perimeter ridge are foraminifer grainstones intercalated with the black, organic-rich clays of Unit III at Sites 874 and 877 . Preserved kerogen-type woody material recovered within the clay deposits suggests that a vegetated volcanic island stood above sea level in the interior of the edifice during the initial transgression. The grainstone layers within the clay at Sites 874 and 877 are probably storm deposits derived from a narrow fringe of skeletal carbonate sand at the margin of the edifice. The preservation of the weathering profile and the lack of clay reworked into the overlying limestone at Sites 873,874 , and 877 suggest that burial was rapid during this subsidence-induced transgression.

The fringe of skeletal sands that produced storm deposits in the clay at Sites 874 and 877 transgressed the inner perimeter ridge sites and left behind a series of alternating beds of high and low resistivity, followed by about $5 \mathrm{~m}$ of poorly cemented grainstone (the fringe itself). The thin, alternating-resistivity beds may reflect the increasing influence of storm washovers as the fringe of skeletal sands approached the site. These skeletal sands are topped by a high-resistivity layer of rhodolith-rich grainstones (top of Subunit IIF at Site 874). Although nodular algal encrustations occur in very shallow water, they may be more characteristic of gentle slope environments with slow sedimentation rates (Adey and Macintyre, 1973; Ginsburg, 1956; Enos, 1977). Camoin et al. (this volume) interpret the base of this rhodolith-rich interval as a maximum flooding surface and the interval itself as a highstand systems tract.

Before deposition of the carbonate sediments, Site 873 in the platform interior was about $50 \mathrm{~m}$ higher than Sites 874 and 877 ; therefore, Site 873 was flooded sometime after the perimeter ridge sites. Larger benthic foraminifers deposited with sediments at the base of Subunit IIIB at Site 873 indicate that flooding of this site did occur prior the end of late Campanian. The initial sediments deposited at Site 873 are similar in nature to the initial carbonates deposited at the perimeter ridge sites: algal-rich grainstones dominate and downhole logs show the alternation of numerous thin beds of high and medium resistivity. The alternation of grainier and muddier beds probably indicates increasingly frequent storm deposition as the marine transgression brought the sources of carbonate sands and algalrich sediments closer to the site. One significant difference between the initial carbonate sediments at Site 873 and the perimeter-ridge sites is the abundance of organic material mixed with the carbonate deposits in some intervals and the dark coloration that is due primarily to the abundance of finely disseminated pyrite (Subunit IIIB, Site 873 ). The organic material reflects the proximity of Site 873 to the nearby basement high (Fig. 2), which was probably a vegetated volcanic island. This late Campanian transgression converted the muddy slope of the underlying volcano into a shallow carbonate shelf extending seaward from an island.

\section{Early Maastrichtian Aggradation of Skeletal Sands}

This rhodolith layer at Site 874 is sharply overlain by low-resistivity, reddish yellow, grainstones and rudstones (base of Subunit IIE at Site 874 [Fig. 5] and base of Subunit IID at Site 877 [Fig. 6]). This change in lithology apparently coincides with the Campanian/Maastrichtian boundary at Sites 874 and 877 (Fig. 8) and may indicate a return to shallower conditions relative to the underlying rhodolithrich layer. The sands are generally well sorted, with evidence of lowangle cross laminations (Premoli Silva, Haggerty, Rack, et al., 1993; p. 220). A return to shallower conditions would imply a relative sea-level stillstand or fall. On a continually subsiding volcanic island (there is no evidence of volcanic activity and uplift interrupting carbonate deposition) a relative sea-level stillstand or fall requires a eustatic fall that equals or exceeds the rate of subsidence. Haq et al. (1987) propose at the Campanian/Maastrichtian boundary that could have caused relative stillstand or lowstand conditions at Wodejebato. However, because of the very low recovery in these intervals, very little evidence is present that can be used to defend a lowstand origin for these sands. Alternatively, the sand deposits could be sediment washed into continually deepening water as the site of carbonate production transgressed the platform. This scenario also has its problems: sands washed into deeper water would probably contain a greater abundance of planktonic foraminifers, as do the sands from Sites 875 and 876 .

Coeval deposits at Site 873 in the platform interior are also characterized by abundant sand layers. The abundance of skeletal sands at the bases of the inner platform and perimeter ridge sites indicates that the earliest Maastrichtian platform may have grown by the deposition of skeletal sands generated at a number of small patch reefs on a relatively open platform (i.e., no perimeter reef buildup in the earliest Maastrichtian time).

As noted earlier, there is no evidence to link subaerial weathering to the coloration of the lower sands at the inner perimeter ridge sites. These sands may have acquired their coloration as a result of slow sedimentation and/or the availability of an iron source such the basalt edifice that was probably still exposed in the platform interior. The change from stained grainstones to white grainstones between Subunits IIE and IID at the perimeter ridge sites may be the result of an increase in sedimentation rate or may be caused by the increasing distance from the source of iron oxides, namely, the underlying basalt or the subsiding central volcanic island. Near the top of Subunit IID 
at Site 874 (137 mbsf on Fig. 8), the grainstones are replaced by less well-sorted, coarser packstones. This is the start of an upward increase in resistivity that ends at about $130 \mathrm{~m}$ below Site 873 seafloor. This interval may represent a shallowing upward during initial aggradation of the rudist-coral-algal shelf.

\section{Maastrichtian Aggradation of the Inner Perimeter Ridge}

Subunit IIC at Sites 874 and 877 is characterized by eight shallowing upward cycles that appear on the resistivity logs as a series of sawtooth increases in resistivity (Fig. 5). In the recovered core, these cycles appear as alternating grainstones and well-cemented framestones and boundstones. The inner perimeter ridge apparently grew as carbonate sands repeatedly migrated across the ridge and were then stabilized by rudist-coral-algal communities. As the perimeter ridge grew, it probably took on an appearance similar to a modern day atoll: reef surrounding a lagoon. At the same time in the platform interior (Site 873, Subunit IIIA-2), deposition of wackestone, mudstone and matrix in the packstones became more common. The coeval growth of a perimeter ridge probably restricted circulation enough in the interior region of the platform to permit deposition of fine-grained sediments. The thickness of alternating high-and medium-resistivity beds increases from the bottom of Subunit IIIB to the top of Subunit IIIA-2 at Site 873; this may be the result of a general reduction in sedimentation rate, or the fact that as the platform aggrades, only the more infrequent, large storms are able to transport significant amounts of coarse sediment to the interior site. During this period of aggradation of the perimeter ridge and deepening at Site 873 , the amount of organic matter at Site 873 decreases from Subunit IIIB to Subunit ПА-2 indicating that the source, a central, vegetated volcanic island, may have subsided below sea level.

\section{Possible mid-Maastrichtian Subaerial Exposure}

Subunit IIIA-2 at Site 873 ends with an apparent exposure surface identified by rhizoliths, alveolar texture, and possible vadose silts that have negative carbon-isotope compositions (Lincoln et al., this volume). Although no ${ }^{13} \mathrm{C}$ depletion was noted in carbonates from Sites 874 or 877 , there is a significant ${ }^{18} \mathrm{O}$ depletion at the top of Subunit IIC from Site 874 and from similar depths at Site 877 that has been interpreted as evidence for diagenesis in meteoric waters (Wyatt et al., this volume; Enos et al., this volume). Enos et al. (this volume) also point out that shallow-marine cements occupy dissolution pores at 48.75 and 42.35 mbsf in Hole 877A (top of Subunit IIC), implying that dissolution occurred before submergence of the platform. The exposure surface at Site 873 is about $88 \mathrm{mbsf}$. This is equivalent to about $47 \mathrm{mbsf}$ at Site 874 , which is about $10 \mathrm{~m}$ below the top of Subunit IIC.

Subunit IIB at the inner perimeter ridge sites suggests deposition in a lagoonward environment relative to the underlying subunit. One scenario that may explain this shift in facies and the apparent exposure at the tops of Subunit IIC on the inner perimeter ridge and Subunit IIIA-2 at Site 873 follows: A relative lowering of sea level may have exposed the inner perimeter ridge and caused a seaward shift of the center of reef accumulation. Site 873, in the interior of the platform, would also become very shallow or would be exposed at this time. When relative sea level rose again, the center of reef accumulation was seaward of Sites 874 and 877 , and sediments of a lagoonward nature were deposited at these two sites. It would have taken a minimum sea-level fall of $10 \mathrm{~m}$ to expose the lagoon, assuming that the sea level before the fall was at the top of Subunit IIIC on the inner perimeter ridge. The relative sea-level fall may have been as much as $40 \mathrm{~m}$ or more, as the top of Subunit IIC at Site 877 is $30 \mathrm{~m}$ higher than at Site 874 . Between the Campanian/Maastrichtian boundary at Sites 874 (Fig. 8) and the top of Subunit IIC, approximately $107 \mathrm{~m}$ of sediment was deposited. This sediment was deposited before the sea-level fall called for in the scenario considered here. Based on possible subsidence rates of $29 \mathrm{~m} / \mathrm{m} . y$. (see discussion at the end of the last section), this apparent sea-level fall occurred about $3 \mathrm{~m}$.y. into Maastrichtian time. Haq et al. (1987) propose a mid-Maastrichtian eustatic fall at about $71 \mathrm{Ma}$ that fits the timing of the possible relative sea-level fall recorded in the carbonate platform at Wodejebato.

\section{Deposition at the Outer Perimeter Ridge}

This mid-Maastrichtian sea-level fall may be the time when Campanian sediments (if there ever were any) were eroded from the basalts at Sites 875 and 876 . If this were the case, the sea-level fall would have been rather large, since the basalt at the outer perimeter ridge sites is about $150-160 \mathrm{~m}$ below the top of Subunit IIC (possible exposure surface) at Sites 874 and 877 and the possible exposure surface at Site 873. The limestone cores at the base of Sites 875 and 876 on the outer perimeter ridge contain the late Campanian Pseudorbitoides cf. trechmani but also contain the Maastrichtian Omphalocyclus. This means that deposition began in Maastrichtian time at Sites 875 and 876, and that part of what was deposited included an older assemblage, possibly eroded from an exposed platform. The recovery of corroded lithoclasts in the packstones near the bottom of Sites 875 and 876 (Subunit IIB) also supports the hypothesis of platform exposure and erosion during initiation of deposition at the outer perimeter ridge.

If a major sea-level fall did take place before deposition of the outer perimeter ridge, then we might expect to see clear evidence of karstification of the platform. This is not the case. Rather, we observe only vague hints that substantial portions of the platform may have been exposed above sea level. For example, numerous cavities filled with geopetal micrite and in some cases planktonic foraminifers have been noted down into the lower reef facies on the inner perimeter ridge (Subunit IIC). However, carbon and oxygen isotope data show no more than a slight shift to lighter oxygen and carbon from initial to later cement generations and these shifts are only apparent near the top of the subunits that would have been exposed. Isotopic data do show significant shifts to lighter carbon and oxygen values for altered skeletal components and cements in Subunit IIIA-1 at Site 873 as well as the presence of meniscus cements. Based on the scenario just presented, however, Subunit IIIA-1 at Site 873 is probably coeval with the outer perimeter ridge sands and therefore did not exist when deposition of the outer perimeter ridge began. No large-scale solution cavities were observed at any site.

Enos et al. (this volume) conclude that the outer perimeter ridge is a constructional, spit-like feature that formed in shallow water during a rise in sea level. The pile of sands may have originated as a spit comprised of some material eroded during a lowstand followed by the accumulation of sand generated by a coeval reef on the inner perimeter ridge during a subsequent sea level rise. If all of the sands at Sites 875 and 876 were formed by erosion of an exposed ridge, we would expect to see many more lithoclasts in the sand and continued mixing of older and younger foraminifer assemblages. This is not the case, lithoclast abundance is greater at the base of the sands as is mixing of assemblages.

Enos et al. (this volume) also propose that the trough separating the two perimeter ridges may be depositional rather than erosional in nature. This would probably require that the entire sand pile be deposited close to sea level during a sea-level rise, which in turn would require that the inner perimeter ridge be exposed the entire time. If the sands on the outer perimeter ridge were deposited while the inner ridge was still active, this would require initial depositional depths at the outer perimeter ridge in excess of $100 \mathrm{~m}$ (the elevation difference between top of Subunit IIC on the inner perimeter ridge and base of the outer perimeter ridge sand pile). We might expect more of a depositional wedge rather than a distinct ridge if deposition of the outer perimeter ridge sands took place in deep water. The trough separating the two ridges would then have to be erosional in nature, necessitating another exposure of the platform (post-outer perimeter ridge deposition). More on this will follow. 


\section{Final Interval of Deposition}

The uppermost platform carbonate subunits recovered at the inner perimeter ridge sites indicate a transgression of the reef facies (Subunit IIA) over the lagoonward deposits of Subunit IIB. A retrograde shift of facies may have resulted from such a rapid rise in relative sea level (subsidence + eustatic rise) that carbonate production could not keep pace. At Site 873, this shift in facies is apparent in the abundance of grainier textures in Subunit IIIA-1 deposited over the more lagoonal mudstones, wackestones, and packstones of Subunit IIIA-2. The increase in algal encrustations and small rudist colonies at the top of Site 873 may suggest growth of small patch reefs in a relatively open lagoon, an environment similar to that of the early Maastrichtian transgression discussed earlier. These upper facies at Sites 873, 874, and 877 are apparently coeval with the sands deposited at Sites 875 and 876 on the outer perimeter ridge based on the presence of Omphalocyclus at all sites.

\section{Possible Late Maastrichtian Subaerial Exposure}

Wodejebato Guyot may possibly have been exposed again following deposition of the early Maastrichtian subunits at Sites 873, 874, and 877 and the outer perimeter ridge sands. Evidence includes molds at the top of the outer perimeter ridge that are filled by early Tertiary pelagic sediment. Presumably, dissolution throughout most of the outer ridge sand deposits took place after subsidence into deep marine waters undersaturated with respect to aragonite (Enos et al., this volume). Was the guyot deep enough by early Tertiary time for the dissolution to occur? If not, then meteoric dissolution may be the culprit. Furthermore, there is clear evidence, discussed in the lithostratigraphic summary above, that the surface of the guyot, including the outer perimeter ridge sites, was eroded substantially before subsidence into the pelagic realm. Subaerial exposure before drowning may also explain the evidence for meteoric diagenesis in Subunit IIIA-1 at Site 873 in the interior of the platform. Small cavity formation was observed shipboard in the limestones recovered at the top of Sites 874 and 877 (e.g., Premoli Silva, Haggerty, Rack et al., 1993, p. 226 , fig. 16). These cavities are filled by mostly early Tertiary pelagic sediments but also include at least some planktonic foraminifers that include $G$. wiedenmayeri, which ranges from the Campanian/Maastrichtian boundary to early late Maastrichtian (about $68 \mathrm{Ma}$ ). These cavities could be the result of a final exposure in mid-Maastrichtian time. As noted earlier, Enos et al. (this volume) proposed two mechanisms for development of the trough that separates the inner and outer perimeter ridges: one depositional (i.e., the result of spit formation) and the other erosional. If the origin of the trough is erosional, then it could have formed during this final subaerial exposure.

Regardless of the means, Wodejebato Guyot probably drowned before or slightly later than $68 \mathrm{Ma}$, based in the age of planktonic foraminifers in the solution cavities near the top of the carbonate platform. If sea-level change played a role, then the late Maastrichtian (about $68 \mathrm{Ma}$ ) sea-level fall of Haq et al. (1987) might be responsible.

\section{Final Drowning of the Carbonate Platform}

So what was the cause of the final drowning at Wodejebato? Possible mechanisms for drowning a reef include the following:

1. A relative drop in sea level, either eustatic in origin or related to uplift of the platform, followed by a rapid relative sea-level rise, has been considered as a drowning mechanism (e.g., Schlager, 1981).

2. Cooling of surface waters could be responsible for reef drowning if carbonate production slows to the point where it cannot keep up with subsidence or sea-level rise. Two possible cooling mechanisms include plate motions that carry the carbonate platform into latitudes that cannot support high rates of carbonate production (e.g., Winterer and Metzler, 1984) or paleoceanographic conditions that cool regional sea surface waters sufficiently for drowning (e.g., Camoin et al., 1993).
3. High nutrient levels have also been proposed as a cause of reduction in carbonate production by hermatypic reef dwellers, such as many of the corals (Hallock and Schlager, 1986).

Schlager (1981) proposed that a carbonate platform might drown during a rapid rise in sea level following by exposure during a sealevel fall. Winterer et al. (1993) suggested that a relative fall caused by either a eustatic fall or thermal/dynamic uplift may have resulted in the demise of carbonate platforms atop guyots in the Mid-Pacific Mountains. To the best of our knowledge, there was no further uplift of Wodejebato Guyot following the cessation of volcanism in early Campanian time. However, we do not know the age of the volcano underlying Pikinni Atoll. Certainly an eruption at Pikinni could affect Wodejebato. An eruption at Pikinni would probably have sent volcaniclastics to the apron drilled at Site 869. No volcaniclastics were recovered at this site after Late Campanian. Even if this guyot was exposed during one or more sea-level falls, this alone does not require that it cease carbonate production. When sea level rises again, why should it not simply resume carbonate production unless there is some other limiting factor involved? Schlager (1981) notes that a healthy reef community should be able to keep up with just about any reasonable rate of sea level rise.

The paleolatitude data presented by Larson et al. (this volume) do not support movement of the Wodejebato Guyot into cooler latitudes at the time of drowning as was suggested for the Mid-Pacific Mountains by Winterer and Metzler (1984). Wodejebato was formed at a low latitude south of the equator and was most likely moving toward warmer latitudes, not cooler latitudes, before drowning.

Camoin et al. (this volume) suggest that drowning of the platform at Wodejebato could possibly coincide with a brief, late Maastrichtian cooling event that may be related to a transition from equatorial to polar-dominated thermohaline circulation (Camoin et al., 1993). This cooling event may have produced rapid sea-level fluctuations. Sealevel fluctuations combined with slower carbonate production rates could possibly have resulted in drowning of the carbonate platform at Wodejebato Guyot.

Hallock and Schlager (1986) postulated that nutrient availability may control the balance between carbonate production and bioerosion on carbonate platforms. This balance between carbonate production and bioerosion may then determine the rate of carbonate sediment accumulation on a platform. Hermatypic corals generally require warm, clear waters to thrive. Hallock and Schlager (1986) noted that hermatypic corals also thrive in some of the most nutrient-deficient waters of the subtropical and tropical seas. They suggest that high plankton densities in nutrient-rich waters reduce water transparency, thereby reducing the efficiency of the photosynthetic zooxanthellae. Higher plankton abundance does provide more food for suspension and filter feeders; however, Hallock and Schlager (1986) point out that overfeeding of zooxanthellate corals can cause excess mucus production, which then fosters bacterial blooms in the mucus, thereby killing the coral. They also point out that fast-growing, nonhermatypic organisms more effectively utilize abundant nutrients, thereby suppressing coral recruitment when nutrient levels are high. Hallock (1988) points out that nutrient excess also increases bioerosion rates; populations of bio-eroders thrive in nutrient-rich waters. Even if the framework builders survive nutrient enrichment, the framework will be broken down into sand and mud-sized grains, which may then be more susceptible to physical and chemical erosion. Therefore, carbonate platforms where framework builders dominate (low-nutrient levels) may be able to better keep up with fluctuations in sea level than one where bioerosion reduces the framework to sediments.

Hallock (1988) suggested several facies models that are dependent on nutrient levels. She suggested that reef framework and skeletal sands should dominate and mud production should be limited in nutrient-poor waters. Therefore, grainstones and framestones should dominate in high-energy, low-nutrient environments, while packstones and rudstones will dominate in low-energy, low-nutrient envi- 
ronments. As nutrient levels increase, the abundance of framestones decreases while mud-rich facies (mudstones and wackestones) become more abundant. The present-day Marshall Islands are lownutrient environments. Deep drilling on Anewetak and Pikinni Atolls (Fig. 1) showed an overwhelming predominance of reef limestone and skeletal sands compared with only limited calcareous muds. Drilling on Wodejebato yielded abundant skeletal sands at Sites 875 and 876 on the outer perimeter ridge, algal-coral-rudist boundstone and framestone and skeletal sands with only a few muddy horizons at Sites 874 and 877 on the inner perimeter ridge, and packstones and grainstones alternating with mudstone or wackestone, as well as some intervals rich in skeletal sands, at Site 873 in the lagoon. Based on the Hallock (1988) models, these results suggest that nutrient levels in the Marshall Islands were also low during that portion of the Late Cretaceous when limestones were accumulating on Wodejebato Guyot.

There is some evidence of an increase in the abundance of calcareous algae and bindstone at the top of Sites 873, 874 and 877 . For example, the platform carbonates at Site 874 are capped by a stromatoporoid-algal-coral bindstone facies (Camoin et al., this volume). Rhodoliths, rare throughout most of the lagoonal Site 873, are present in a few of the cores from the top of the platform unit (Lincoln et al., this volume). Increased occurrence of bindstone and calcareous algae is characteristic of Hallock's (1988) mesotrophic to slightly eutrophic facies models. These algal-rich facies may be an indication that the guyots have moved from nutrient-poor (oligotrophic) conditions to nutrient-enriched conditions.

The uppermost carbonate-platform facies recovered at all sites on Wodejebato consists of packstones and rudstones that have been phosphatized and encrusted with ferro-manganese oxides. This facies typically separates drowned, shallow-water, reef deposits from overlying deep-water deposits (Schlager, 1981). Hallock (1988) suggests that this facies is consistent with excess nutrient levels. She notes that high nutrient levels promote the growth of algal-bacterial mats that may aid in the formation of hardgrounds. Abundance of organic matter that results from the high nutrient supply may reduce oxygen levels sufficiently for formation of authigenic minerals in and on the hardground.

The latitude at which the carbonate platform on Wodejebato drowned is between $4^{\circ}-8^{\circ}$ South (Larson et al., this volume); this coincides with the paleoequatorial upwelling zone of high nutrient availability and productivity. As Wodejebato entered this zone of high nutrient availability, water transparency decreased and the growth rate of algal-symbiont-bearing organisms such as corals, larger benthic foraminifers, and possibly rudist bivalves may have decreased. As nutrient availability increased, populations of bio-eroders increased and net carbonate production dropped. If late Maastrichtian cooling was a factor, as suggested by Camoin et al. (this volume), then carbonate production rates would be lowered even further. The increase in temperature that would take place as these guyots approached the equator could also have played a role in the demise of their reefs. In present Pacific reefs, El Niño warming events produce coral bleaching, or the inability of the corals to retain zooxanthellae in their tissues. This has resulted in widespread destruction of modern reefs (e.g., Galapagos Islands during the 1982-83 El Niño). Warming during the approach to the equator may have contributed to demise of the platform community. The reduced rate of carbonate production could not keep up with subsidence of the guyot plus a eustatic rise, leading to the final drowning of the guyots.

This mechanism of drowning may explain how Wodejebato Guyot could drown while Pikinni Atoll to the southeast is still accumulating carbonate sediment. While Wodejebato was drowning at $4^{\circ}-8^{\circ} \mathrm{S}$ latitude in Maastrichtian time, its neighbor Pikinni either had not formed yet or was an emergent volcanic island. The basalt beneath Pikinni has never been sampled. Since there is no evidence for any eruption in the area post-Campanian time at Site 869, Pikinni probably was emergent. If Pikinni did not subside out of the photic zone until it was north of the nutrient-rich crisis zone, then a living atoll could then accumulate adjacent to a guyot capped by a failed carbonate platform.

\section{CONCLUSIONS}

The volcanic edifice of Wodejebato Guyot in the northern Marshall Islands first began to erupt before or during mid-Cenomanian time. This phase of eruption produced thick deposits of volcaniclastic debris at Site $869,83 \mathrm{~km}$ southeast of the guyot and a vegetated volcanic island.

At Site 869 , the abundance of volcaniclastic debris is greatly reduced from Turonian time to earliest Campanian, suggesting a period of quiescence for the volcano at Wodejebato. Redeposited Cenomanian nannofossils recovered in Campanian clays at Site 877 as well as Santonian to earliest Campanian planktonic foraminifers in rocks dredged from the slopes of the atoll suggests some period of at least partial submergence of the volcano before reactivation in early Campanian time.

A second phase of volcanic activity was confined to early Campanian time. This eruption is apparent in the renewed abundance of volcaniclastic debris at Site 869 during the early Campanian. This is also the age of all volcanic material recovered by drilling at Sites 873-877 on Wodejebato Guyot.

Once again a volcanic island rose above sea level. During this emergent period, a tropical weathering profile, up to $23 \mathrm{~m}$ thick, developed atop the basalts and breccias of the volcanic island. Woody plant material was recovered at sites drilled on the guyot, suggesting this island was vegetated.

Carbonate sands that were later stabilized by encrusting organisms such as red algae were laid down in late Campanian time as subsidence of the underlying edifice carried the summit down to, and eventually below, the sea level.

The first Maastrichtian deposits are predominantly carbonate sands with some rhodolith-rich layers and some muddier layers, especially at the platform interior site. These deposits may indicate that the earliest Maastrichtian platform at Wodejebato grew by deposition of sands generated by small patch reefs scattered across an open platform; a fringing ridge did not form until later.

Following the initial transgression of the volcanic island and deposition of tens of meters of skeletal sand deposits in earliest Maastrichtian time, an aggrading algal-coral-rudist boundstone and framestone reef formed a ridge along the perimeter of the platform. The growth of a perimeter ridge resulted in progressively quieter, more restricted depositional environments at Site 873 on the interior of the platform.

The carbonate platform may have experienced exposure above sea level in mid-Maastrichtian time. This relative fall in sea level is marked by evidence of diagenesis in meteoric waters at the similar depths at Sites 873,874 , and 877 . This apparent exposure is followed by distinct facies shifts at all three of these sites. This sea-level fall may be coeval with the onset of deposition at Sites 875 and 876 on the outer perimeter ridge. At this time, sediments seaward of the inner perimeter ridge (Site 875 and 876 ) may have eroded down to the underlying basalt. This basalt was soon covered with a ridge, or spit, formed from skeletal sands eroded from the inner perimeter ridge.

As the sea level rose again and a new coral-algal-rudist reef reestablished itself on the inner perimeter ridge, sands continued to accumulate into an outer perimeter ridge essentially parallel to the inner ridge. Sand shoals also migrated across the lagoonal sediments on the interior of the platform, followed by colonization of these sands by algae and rudist colonies.

A second relative sea-level fall in late Maastrichtian time may have exposed the surface of the platform to erosion and meteoric diagenesis a second time; there is evidence for scouring of the terminal carbonate deposits, evidence of solution in the upper limestone subunits, and isotopic evidence for diagenesis in meteoric waters. 
Following this late Maastrichtian exposure, possible cooling of the oceans and high nutrient availability in waters encountered by the guyot as the underlying Pacific Plate carried it toward the equator may have slowed carbonate production to the point that the platform could not reestablish itself, or keep up, during a subsequent sea-level rise. Based on the age of planktonic foraminifers in some of the solution cavities, demise of the platform occurred before about $68 \mathrm{Ma}$, or shortly thereafter.

\section{REFERENCES}

Adey, W.H., and McIntyre, I.G., 1973. Crustose coralline algae: a reevaluation in the geological sciences. Geol. Soc. Am. Bull., 84:883-904.

Al-Aasm, I.S., and Veizer, J., 1986. Diagenetic stabilization of aragonite and low-Mg Calcite, II. Stable isotopes in rudists. J. Sediment. Petrol., 56:763770 .

Alldredge, L.R., Keller, F., and Dichtel, W.J., 1954. Magnetic structure of Bikini Atoll. Geol. Surv. Prof. Pap. U.S., 260-M:529-536.

Bergersen, D.D., 1993. Geology and geomorphology of Wodejebato (Sylvania) Guyot, Marshall Islands. In Pringle, M.S., Sager, W.W., Sliter, W.V., and Stein, S. (Eds.), The Mesozoic Pacific: Geology, Tectonics, and Volcanism. Geophys. Monogr., Am. Geophys. Union. 77:367-385.

Bourrouilh, F.G., 1979. Les plates-formes carbonatees de haute energie a Rhodolites et la crise climatique du passage mio-pliocene dans le domaine pacifique. Bull. Cent. Rech. Expl.-Prod. Elf-Aquitaine, 3:489-495.

Camoin, G., Bellion, Y.J.C., Dercourt, J., Guiraud, R., Lucas, J., Poisson, A., Ricou, L.E., and Vrielynck, B., 1993. Late Maastrichtian (69.5-65 Ma). Explanatory notes. In Dercourt, J., Ricou, L.E., and Vrielynck, B. (Eds.), Atlas Tethys Paleoenvironmental Maps: Paris (Gauthier Villars), 179-196.

Camoin, G., Bernet-Rollande, M.-C., and Philip, J., 1988. Rudist-coral frameworks associated with submarine volcanism in the Maastrichtian strata from Pachino area (S.E. Sicily). Sedimentology, 35:128-143.

Cole, W.S., 1954. Larger foraminifera and smaller diagnostic foraminifera from Bikini drill holes. Geol. Surv. Prof. Pap. U.S., 260-O:569-608.

1957. Larger foraminifera from the Eniwetok atoll drill holes. Geol. Surv. Prof. Pap. U.S., 260-V:743-784.

Collot, J.-Y., Greene, H.G., Stokking, L.B., et al., 1992. Proc. ODP, Init. Repts., 134: College Station, TX (Ocean Drilling Program).

Detrick, R.S., and Crough, S.T., 1978. Island subsidence, hot spots, and lithospheric thinning. J. Geophys. Res., 83:1236-1244.

Emery, K.O., Tracey, J.I., Jr., and Ladd, H.S., 1954. Geology of Bikini and Nearby Atolls. Geol. Surv. Prof. Pap. U.S., 260-A.

Enos, Paul, 1977. Holocene sediment accumulations of the south Florida shelf margin. In Enos, Paul, and Perkins, R.D. (Eds.), Quaternary Sedimenta. tion in South Florida. Mem.-Geol. Soc. Am., 147:1-130.

Freeman-Lynde, R.P., Fulker Whitley, K., and Lohmann, K.C, 1986. Deepmarine origin of equant spar cements in Bahama Escarpment limestones. J. Sediment. Petrol., 56:799-811.

Ginsburg, R.N., 1956. Environmental relationships of grain size and constituent particles in some south Florida carbonate sediments. AAPG Bull., 40:2384-2427.

Gonzalez, L.A., and Lohmann, K.C, 1985. Carbon and oxygen isotopic composition of Holocene reefal carbonates. Geology, 13:811-814.

Gross, G.M., and Tracey, J.I., 1966. Oxygen and carbon isotope composition of limestones and dolomites, Bikini and Anewetak atolls. Science, 151:1082-1084.

Hallock, P., 1988. The role of nutrient availability in bioerosion: consequences to carbonate buildups. Palaeogeogr., Palaeoclimatol., Palaeoecol., 63:275-291.

Hallock, P., and Schlager, W., 1986. Nutrient excess and the demise of coral reefs and carbonate platforms, Palaios, 1:389-398.

Hamilton, E.L., and Rex, R.W., 1959. Lower Eocene phosphatized Globigerina ooze from Sylvania Guyot. Geol. Surv. Prof. Pap. U.S., 260-W:785797.
Haq, B.U., Hardenbol, J., and Vail, P.R., 1987. The new chronostratigraphic basis of Cenozoic and Mesozoic sea level cycles. Spec. Publ. Cushman Found. Foraminiferal Res., 24:7-13,

Land, L.S., 1970. Phreatic vs. vadose meteoric diagenesis of limestones: evidence from a fossil water table. Sedimentology, 14:175-185.

Land, L.S., and Epstein, S., 1970. Late Pleistocene diagenesis and dolomitization, North Jamaica. Sedimentology, 14:187-200.

Lincoln, J.M., 1988. Isotopic record of marine diagenesis from Eocene reef limestones recovered from Harrie Guyot, Marshall Islands. Geol. Soc. Am. Abstr. Progr., 20:A260-A261.

Lincoln, J.M., Pringle, M.S., and Premoli-Silva, I., 1993. Early and Late Cretaceous volcanism and reef-building in the Marshall Islands. In Pringle, M.S., Sager, W.W., Sliter, W.V., and Stein, S. (Eds.), The Mesozoic Pacific: Geology, Tectonics, and Volcanism. Geophys. Monogr., Am. Geophys. Union, 77:279-305.

Parsons, B., and Sclater, J.G., 1977. An analysis of the variation of ocean floor bathymetry and heat flow with age. J. Geophys. Res., 82:803-829.

Petersen, L.D., Duennebier, F.K., and Shipley, T.H., 1986. Site surveys in the western Pacific conducted aboard the Kana Keoki, Cruise KK810626 Leg 4. In Moberly, S., Schlanger, S.O., et al., Init. Repts. DSDP, 89: Washington (U.S. Govt. Printing Office), 604-628.

Premoli Silva, I., 1986. A new biostratigraphic interpretation of the sedimentary record recovered at Site 462, Leg 61, Nauru Basin, western equatorial Pacific. In Larson, R.L., Schlanger, S.O., et al., Init. Repts. DSDP, 61: Washington (U.S. Govt. Printing Office), 311-319.

Premoli Silva, I., Haggerty, J., Rack, F., et al., 1993. Proc. ODP, Init. Repts., 144: College Station, TX (Ocean Drilling Program).

Raitt, R.W., 1954. Seismic refraction studies of Bikini and Kwajalain atolls and Sylvania Guyot. Geol. Surv. Prof. Pap. U.S., 260-K:507-528.

Sager, W.W., Winterer, E.L., Firth, J.V., et al., 1993. Proc. ODP, Init. Repts., 143: College Station, TX (Ocean Drilling Program).

Saller, A.H., 1986. Radiaxial calcite in lower Miocene strata, subsurface Enewetak Atoll. J. Sediment. Petrol., 56:743-762.

Sandberg, P.A., and Hudson, J.D., 1983. Aragonite relic preservation in Jurassic calcite-replaced bivalves. Sedimentology, 30:879-892.

Schlager, W., 1981. The paradox of drowned reefs and carbonate platforms. Geol. Soc. Am. Bull., 92:197-211.

Schlanger, S.O., 1963. Subsurface geology of Eniwetak Atoll. Geol. Surv. Prof. Pap. U.S., 260-BB:991-1066.

, 1986. Oligocene sea-level fall recorded in mid-Pacific atoll and archipelagic apron settings. Geology, 14:392-395.

Serra, O., 1989. Shallow water carbonate environment. In Sedimentary Environments from Wireline Logs (2nd ed.): Houston, TX (Schlumberger Well Services), 199-211.

Skelton, P.W., 1979. Gregariousness and proto-cooperation in rudists (bivalvia). In Larwood, G., and Rosen, B.R. (Eds.), Biology and Systematics of Colonial Organisms. Spec. Publ. Syst. Assoc., 11:257-279.

Winterer, E.L., and Metzler, C.V., 1984. Origin and subsidence of guyots in Mid-Pacific Mountains. J. Geophys. Res., 89:9969-9979.

Winterer, E.L., Natland, J.H., van Waasbergen, R.J., Duncan, R.A., McNutt, M.K., Wolfe, C.J., Premoli Silva, I., Sager, W.W., and Sliter, W.V., 1993. Cretaceous guyots in the Northwest Pacific: an overview of their geology and geophysics. In Pringle, M.S., Sager, W.W., Sliter, W.V., and Stein, S. (Eds.), The Mesozoic Pacific: Geology, Tectonics, and Volcanism. Geophys. Monogr., Am. Geophys. Union, 77:307-334.

\footnotetext{
Abbreviations for names of organizations and publication titles in ODP reference lists follow the style given in Chemical Abstracts Service Source Index (published by American Chemical Society).
}

Date of initial receipt: 2 August 1994

Date of acceptance: 13 January 1995 Ms 144SR-064 